九州大学学術情報リポジトリ

Kyushu University Institutional Repository

Weevils of the Tribe Acalyptini (Coleoptera: Curculionidae: Curculioninae): Redefinition and a Taxonomic Treatment of the Japanese, Korean and Taiwanese Species

Koj ima, Hiroaki

The Kyushu University Museum, Kyushu University

Morimoto, Katsura

The Kyushu University Museum, Kyushu University

https://doi.org/10.5109/2704

出版情報: ESAKIA. 45，pp.69-115，2005-03-31. Entomological Laboratory，Faculty of Agriculture， Kyushu University

バージョン：

権利関係 : 


\title{
Weevils of the Tribe Acalyptini (Colleoptera: Curculionidae: Curculioninae): Redefinition and a Taxomomic Treatment of the Japanese, Korean and Taiwanese Species
}

\author{
Hiroaki KoJima and Katsura MoRimoto
}

The Kyushu University Museum, Kyushu University, Fukuoka, 812-8581 Japan

\begin{abstract}
The tribe Acalyptini is redefined, distinguished from the tribe Derelomini and placed in the subfamily Curculioninae. Most genera classified in Derelomini from Asia are transferred to Acalyptini: Derelomorphus Marshall, Eudela Pascoe, Eudelodes Zimmerman, Meredolus Marshall, Nodocnemus Marshall and Tithene Pascoe. Thus, at least in the Malesia (Malay Peninsula to New Guinea), Pacific islands and also Australia, weevils associated with the flowers of palms belong not to Derelomini but to Acalyptini except for introduced species. The genera Orsophagus Roelofs and Imera Pascoe, which were synonymized with Acalyptus Schoenherr and Amorphoidea Motschulsky, respectively, are resurrected to the status of full genera. All the genera classified in Acalyptini are briefly reviewed and a key to them is provided. Japanese, Korean and Taiwanese species are treated taxonomically, and a total of 5 genera and 7 species are recognized including the following new species: Orsophagus subfasciatus [Japan, Taiwan and Thailand], Parimera flava [Japan], P. subflava [Taiwan] and Imera formosana [Taiwan]. Amorphoidea gossyppi (Pierce) known from the Philippines is synonymous with $A$. lata, one of the famous pests of cotton in the Philippines. The genera Imera and Parimera are recorded in this area for the first time.
\end{abstract}

Key words: Acalyptini, Derelomini, redefinition, taxonomy, pollinator, palms

\section{Introduction}

As is often referred to as 'flower weevils', members of Curculioninae are generally associated with inflorescences. Thus, in the case of large numbers of adults are attracted to flowers, they become pests of the plant. On the other hand, some of them such as Acalyptini and Derelomini treated in this paper are involved in cantharophily (pollination by beetles). For instance, Derelomini auct. are considered to be the most important category of entomophily in palms 
(Henderson, 1986). However, except for some cultivated plants, quite a few are known for weevil pollinators, which are actually extraordinarily diverse in nature, particularly in the tropics.

This study reveals the delimitation of Acalyptini, which has often been confused with Derelomini from the viewpoint of comparative morphology. Redefinition of Acalyptini changes our previous understanding that weevils associated with the flowers of palms are not Derelomini but is Acalyptini at least in the Malesia (Malay Peninsula to New Guinea), Pacific islands and also Australia except for introduced species.

One of the peculiar features of Acalyptini is the 'pygidium' which is broadly exposed from the subtruncate to truncate elytral apices (ex. Reitter, 1912; Morimoto, 1962c etc.). Among weevils, however, the 'pygidium' is exposed in various degrees in some taxa independently. The 'pygidium' usually is defined as tergite 8 in the male and that of tergite 7 in the female as a rule in Curculionidae. But, it is revealed that the broadly exposed segment in Acalyptini is tergite 7 , the so-called propygidium, and tergite 8 is broadly or mostly concealed beneath it in the male. This feature is known in Anthribidae, Attelabidae, Platypodidae, Scolytidae and Dryophthoridae (=Rhynchophoridae), but it had not been observed previously in Curculionidae. Thus, we believe that this is one of the good features to discriminate Acalyptini from other curculionid weevils.

Acalyptini were first established by Thomson (1859) as 'Tribus Acalyptina' for the genera Acalyptus Schoenherr and Miarus Schoenherr, but the latter is now classified in Gymnaetrinae or Curculioninae: Mecinini in the recent catalogue by Alonso-Zarazaga \& Lyal (1999). Also, Acalyptini have been classified variously in Erirhininae (Klima, 1934), Anthonominae (Voss, 1953, 1958), and Curculioninae (Lohse, 1983; Zherikhin \& Egorov, 1990, Egorov et al., 1996) or treated independently as Acalyptinae (Marshall, 1937b; Morimoto, 1962c). In the Coleopterorum Catalogus, Klima (1934) included the New World genera Ephelops Dietz, Epimechus Dietz and Xanthus Dietz (=Dietzianus Sleeper) in this tribe, but now they are treated in Anthonomini. Voss (1953) classified his genera Aedenus Voss, Homacalyptus Voss (=Imerodes Marshall) and Sphincticraeropsis Voss in Anthonominae: Acalyptini, but Aedenus and Imerodes are now classified in Ochyromerina, Tychiini. Therefore, Acalyptini contain Amorphoidea Motschulsky, Niseida Pascoe, Parimera Faust and Sphincticraeropsis Voss now (Alonso-Zarazaga \& Lyal, 1999).

While in the New World, Acalyptus, which is represented by one species introduced from the Palearctic region, has been classified in Derelomini under Erirhininae and Acalyptini have never been recognized among American taxonomists (ex. Kissinger, 1964; O'Brien \& Wibmer, 1982). Weevils of Derelomini are generally associated with palms, especially rich in the tropics and similar to Acalyptini at first sight owing to the relatively soft body and general shape or form, and coloration. Derelomini were established by Lacordaire (1866) as 'Tribus Derelomides'. Also, Derelomini have been classified in Erirhininae (Klima, 1934, O'Brien \& Wibmer, 1982, Wibmer \& O'Brien, 1986), Petalochilinae (Voss, 1958, Morimoto, 1962c) following after 
Kuschel (1952), or treated independently as Derelominae (Marshall, 1935; Thompson, 1992). Petalochilinae defined by Kuschel (1952) was, however, drastically modified by himself (1964) and divided into Petalochilini, Trypetidini, Juanorhinini, Amalactini and Derelomini. The first four tribes were classified in Molytinae and the last was placed in Curculioninae by Kuschel (1987) and based on his then unpublished scheme, the first four were treated as independent subfamilies and the last was placed in Erirhininae by Wibmer \& O'Brien (1986).

Though Acalyptini and Derelomini have often been confused among taxonomists, we found the crucial features distinguishing Acalyptini from typical Derelomini. In this paper, Acalyptini are redefined and genera previously classified in Derelomini or the other tribes, mainly from Asia, are newly settled in Acalyptini, together with a taxonomic treatment of Japanese, Korean and Taiwanese species.

\section{Material and method}

Type materials described by Faust, Heller, Lea, and Pascoe were examined at, and/or borrowed from The Natural History Museum, London (BMNH, C. H. C. Lyal), Staatliches Museum für Tierkunde, Dresden (SMTD, R. Krause), Deutsches Entomologisches Institut, Eberswalde (DEI, L. Zerche) and CSIRO, Canberra (R. Oberprieler \& E. C. Zimmerman). Japanese, Korean and Taiwanese species examined are based mostly on the collection preserved in the Entomological Laboratory, Kyushu University, Fukuoka (ELKU). Though 37 genera have been described worldwide, mostly from the Neotropical and Ethiopian regions in Derelomini (Alonso-Zarazaga \& Lyal, 1999), we dissected the type genus Derelomus Schoenherr (D. uenoi, D. bicarinatus \& D. chamaeropis) and Elaeidobius Kuschel (E. kamerunicus) for detailed examination in this study.

The body length was measured as the distance from the anterior margin of eye to the apex of the pygidium in lateral view.

\section{Comparative morphology of selected characters of Acalyptini and typical Derelomini}

Head. The labial palpi are 3-segmented in the majority of Curculionoidea including typical Derelomini, and sometimes 2-segmented in some taxa (Morimoto, 1962b). In Acalyptini, they are often 2-segmented in such genera as Parimera and Amorphoidea of those species we examined (Figs. 35, 36). The antennal club is usually similar in both tribes by having the 1st segment longest and the apical segments more or less compact. An exception is Tithene, in which the 1 st segment is often shorter than the remaining segments combined.

Thorax. The prothorax is simple and not carinate laterally in Acalyptini (Fig. 42), whereas it is sharply carinate along lateral margin in typical Derelomini (Fig. 44). The elytra are truncate or subtruncate at the apices, the 'pygidium' is more or less exposed and the ventral 
margin of the each elytron is simple at the apex, neither ridged nor carinate in Acalyptini. In typical Derelomini, however, the apices of the elytra are rounded, the pygidium is concealed and the ventral margin of the each elytron is submarginally carinate as in most weevils (Fig. 39). The tibiae are simple, unarmed and neither mucronate nor uncinate at the apex in Acalyptini (Figs. 45, 93-96), whereas in typical Derelomini, they are usually mucronate at least on the fore and middle legs (Figs. 46-47). The tarsal claws are similar in both tribes, usually widely divergent, free, and each claw with a setae, but often toothed at the base in Acalyptini. The procoxae are located near the base, distant from the anterior margin of prosternum, and more or less separated from each other in both tribes. On the metasternum, the longitudinal median sulcus is well developed for nearly its entire length in Acalyptini and Elaeidobius of Derelomini, and is about half its entire length in Derelomus. The hind wings have a distinct anal lobe in both tribes. The anterior tendons of the metendosternite are not so widely separated in Acalyptini (Figs. 54, 55), whereas they are separated widely and each of tendons is located at the base of the furcal arm in typical Derelomini (Figs. 56, 57).

Abdomen. In Curculionidae as a rule, the 'pygidium' is formed of the tergite 8 in the male, but in Acalyptini, the tergite 7 (the propygidium) is well-developed, broadly exposed beyond the truncate apices of the elytra and conceals most of the tergite 8 (pygidium) beneath it (Figs. 52,53 ). This feature is regarded to be unique to this tribe among Curculionidae. The tergite 7 is provided with a pair of wing holding spiculate patches on the anterior area in typical Derelomini (Figs. 48-51) as was normally observed in other weevils, but they are absent in Acalyptini (Figs. 52, 53). Additionally, in typical Derelomini, the tergite 7 is provided with setiferous tubercles, which are arranged in a pair of longitudinal rows in the male (Figs. 40, 48, 50). This structure is considered to be for stridulation corresponding with the elytro-tergal stridulation system ('type 2 '*) of Lyal \& King (1996), and may scrape the sub-marginal ridge on the underside of elytra. However in Acalyptini, this structure is not present. The tegmen of the male genitalia is ringed and the parameres are absent in Acalyptini (ex. Fig. 103). In typical Derelomini, the tegmen is provided with a pair of parameres in Derelomus (Figs. 60, 66), but they are absent in Elaeidobius (Fig. 71). The sternite 8 of the male is paired, subtriangular and usually harbors a sclerite between them in Acalyptini (ex. Fig. 104). However, in typical Derelomini, the sternite 8 is sclerotized relatively narrowly, and not paired in Derelomus (Figs. 61, 67) or paired in Elaeidobius (Fig. 72). The spiculum gastrale is nearly straight, symmetrical and provided with a median sclerite in Acalyptini (ex. Fig. 104), whereas it is curved, asymmetrical and not provided with a median sclerite in typical Derelomini (Figs. 61, 67, 72).

* This type of elytro-tergal stridulation system was previously known only in some Cossoninae and Molytinae (Lyal \& King, 1996), and was recently found in the Curculioninae: Anoplini (Kojima $\&$ Morimoto, 2000). Thus, the occurrence of same type of structure in Curculioninae: Derelomini is reported here for the first time. 

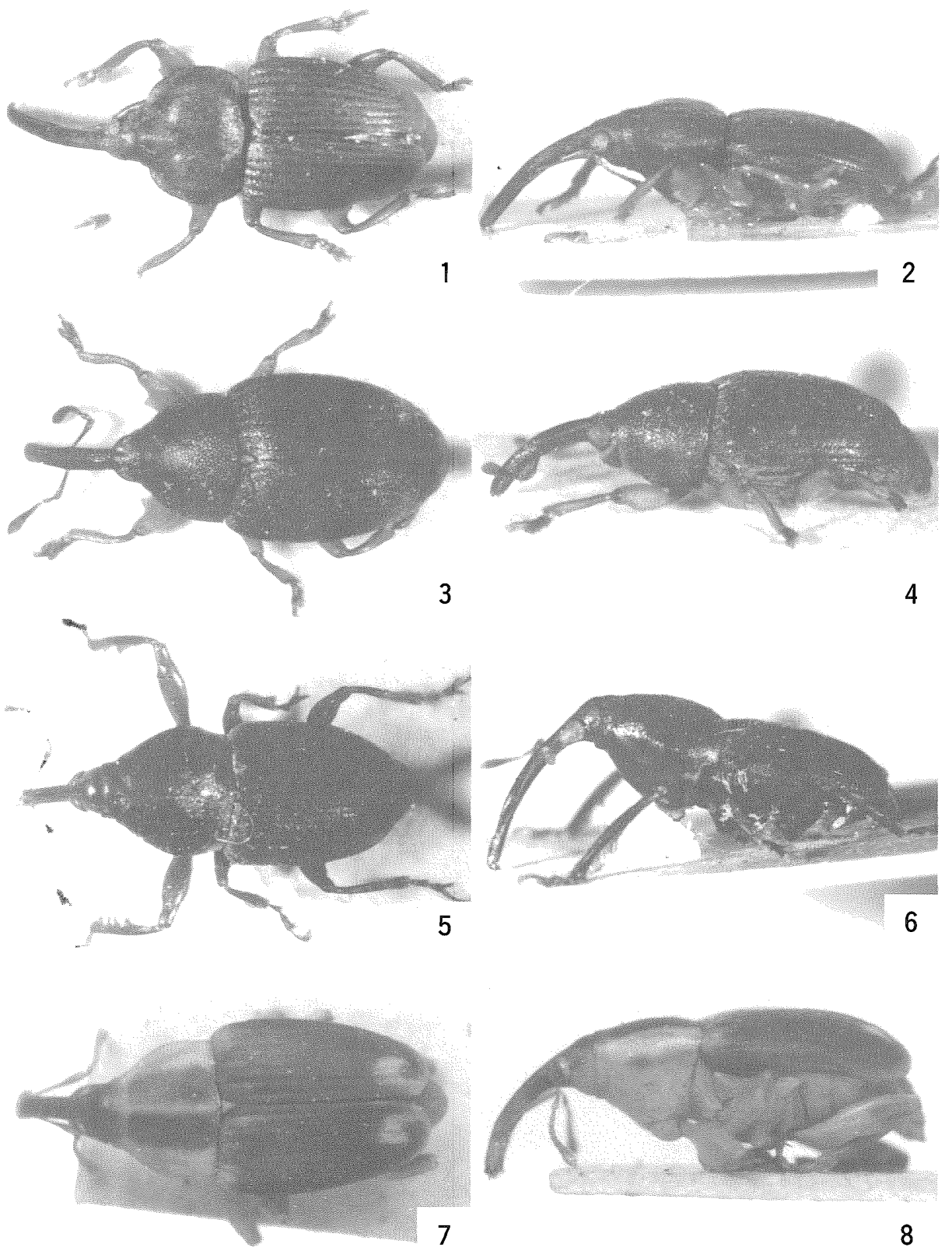

Figs. 1-8. Habitus photos of Acalyptini: 1, 2. Eudela rufescens, holotype; 3, 4. Imera pedestris, holotype; 5, 6. Tithene microcephala, holotype; 7, 8. Parimera signata, holotype. 

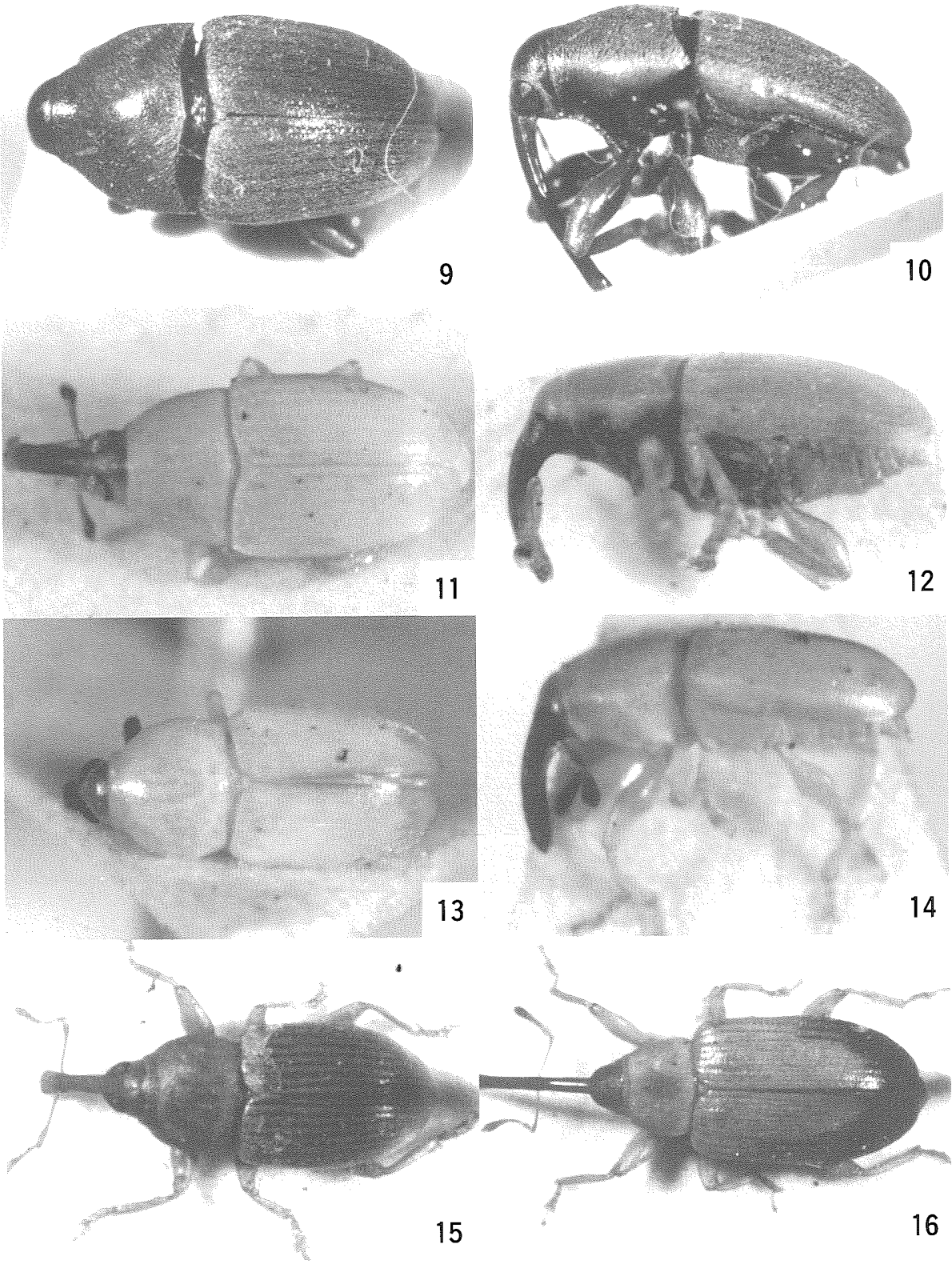

Figs. 9-16. Habitus photos of Acalyptini: 9, 10. Nodocnemus uniformis, holotype; 11, 12. Meredolus cocotis, holotype; 13, 14. Derelomorphus eburneus, holotype; 15. Niseida virginea, holotype; 16. Telphasia diluta, holotype. 


\section{Redefinition of Acalyptini}

Relatively soft-bodied weevils, often with sexual dimorphism evidently in the length and shape of rostrum, the shape of prothorax and the body size, sometimes larger in male than that in female. Labial palpi often 2-segmented. Prothorax not sharply carinate laterally. Elytra truncate to subtructate at apex. Tibiae unarmed at apex. Prosternum with coxae located near base, distant from anterior margin and more or less separated. Metasternum with median longitudinal sulcus well-developed in nearly entire length of metasternum. Metendosternite with pair of anterior tendons not widely separated. Posterior margins of abdominal ventrites 2-4 straight. Tergite 7 exposed beyond apices of elytra, provided with neither wing holding spiculate patch nor tubercles for stridulation, and tergite 8 mostly concealed beneath tergite 7 in both sexes. Aedeagus with tegmen ringed, without paramere. Sternite 8 paired,
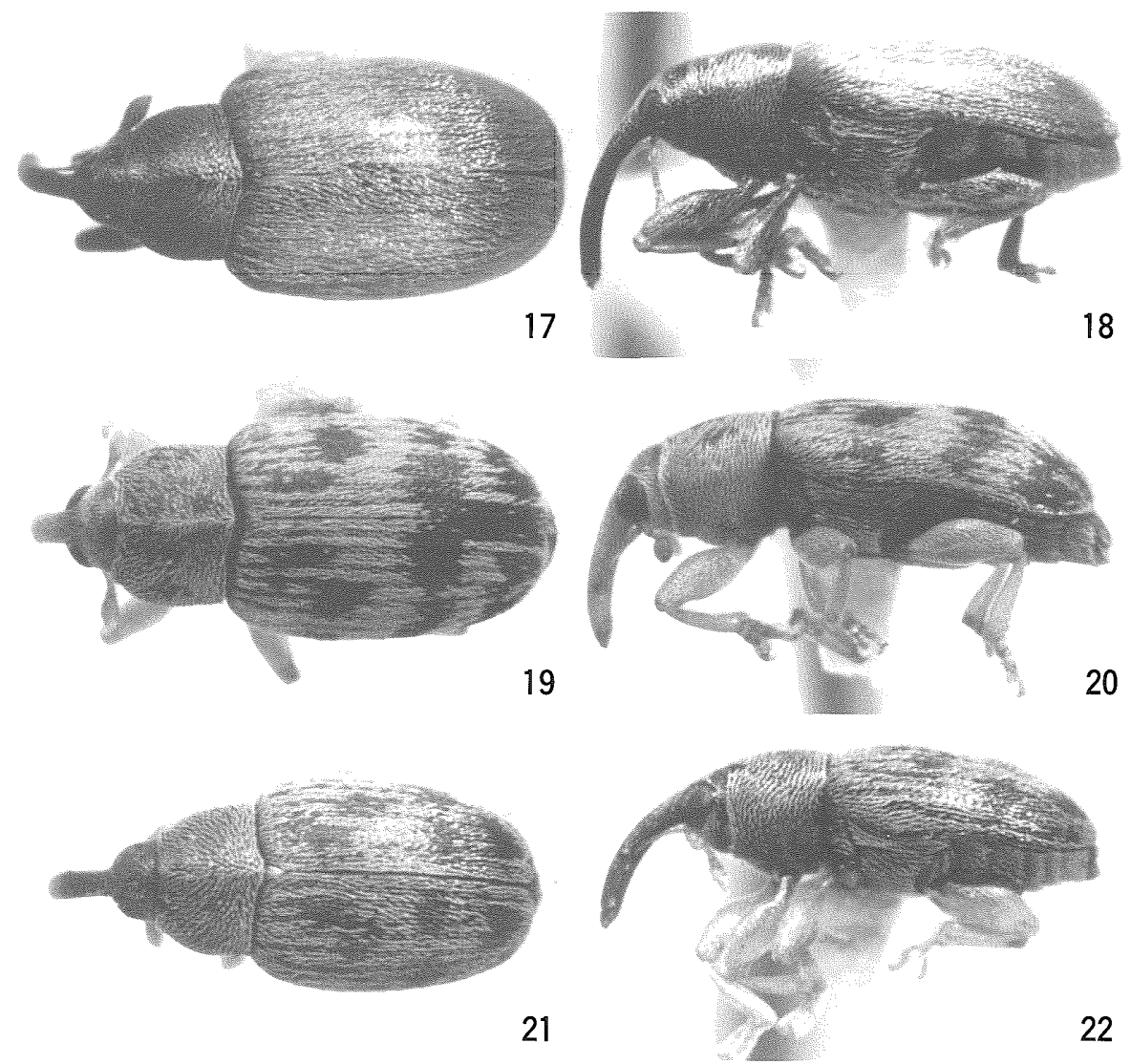

Figs. 17-22. Habitus photos of Acalyptini: 17, 18. Acalyptus carpini; 19, 20. Orsophagus trifasciatus; 21, 22. O. subfasciatus. 
subtriangular, with sclerite between them. Spiculum gastrale almost straight, symmetrical, provided with median sclerite. Spermatheca with ramus indefinite.

\section{Gemera classified in Acalyptini}

Acalyptini had been consisted solely of the genus Acalyptus Schoenherr, but AlonsoZarazaga \& Lyal (1999) included Amorphoidea Motschulsky, Niseida Pascoe, Parimera Faust and Sphincticraeropsis Voss. Among these, Sphincticraeropsis was removed from Acalyptini in having the posterior margins of abdominal ventrites 2-4 curved posteriorly at sides and transferred to Ochyromerini or Ochyromerina, Tychiini (Kojima \& Idris, 2004).

Amorphoidea was established by Motschulsky (1858) and placed near Acalyptus in Erirhinides. Faust (1893) noted that Amorphoidea was similar to Pascoe's genera Telphasia, Niseida and Imera, but nonetheless placed it in 'Laemosacciden'. Marshall (1926) treated it in Anthonominae and placed it near Parimera. In the Coleopterorum Catalogus, Schenkling \& Marshall (1939) assigned it to Erirhininae. Then, Zimmerman (1992, 1994) transferred it from Erirhininae to Derelomini of Curculioninae, and synonymized Ecthetophyga Pierce, 1912 of Menemachinae with Amorphoidea. Zherikhin \& Gratshev (1995) treated it in Acalyptini in their comparative study of hind wing venation, and were followed by AlonsoZarazaga \& Lyal (1999). The latter treatments are considered to be appropriate judging from our definition.

A monotypic genus Niseida was erected by Pascoe (1885) for N.virginea Pascoe (Fig. 15) from Aru in Anthonominae. Klima (1934) treated Niseida in the genera incertae sedis of Erirhininae. Niseida is similar to Eudela in having the integument thinly clothed with setae and also to Acalyptus in having the edentate femora, but separable from both of them by the characters noted in the key, and is classified in Acalyptini as was treated by Alonso-Zarazaga \& Lyal (1999).

Parimera was established by Faust (1896) in 'Anthonominorum' with descriptions of four new species, but he did not designate the type species. Judging from his description, however, the type is regarded as $P$. signata (herein designated; Figs. 7, 8). Parimera was treated in Anthonominae by Schenkling \& Marshall (1934), in Trypetinae by Voss $(1937,1940)$ with Tithene and Amorphoidea, in Petalochilinae by Voss (1961) following the definition of Kuschel (1952), or in Derelomini of Curculioninae by Zimmerman (1992, 1994), but Parimera should be transferred to Acalyptini as it was treated by Alonso-Zarazaga \& Lyal (1999).

Orsophagus is monotypic, established by Roelofs (1874) for O. trifasciatus Roelofs (Figs. 19, 20) from Japan and placed in 'Erirhinides vrais'. This treatment was followed by Kôno (1930) as in Erirhini or Klima (1934) as in Erirhinini, Erirhininae. Although Morimoto (1983) synonymized Orsophagus with Acalyptus, they can be distinguished by some 


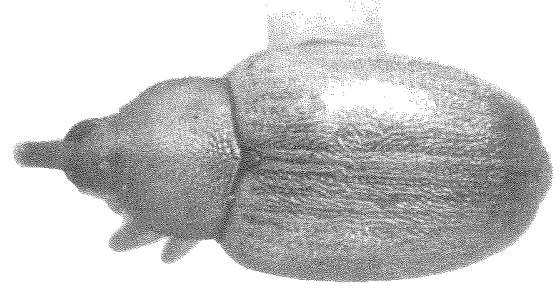

23
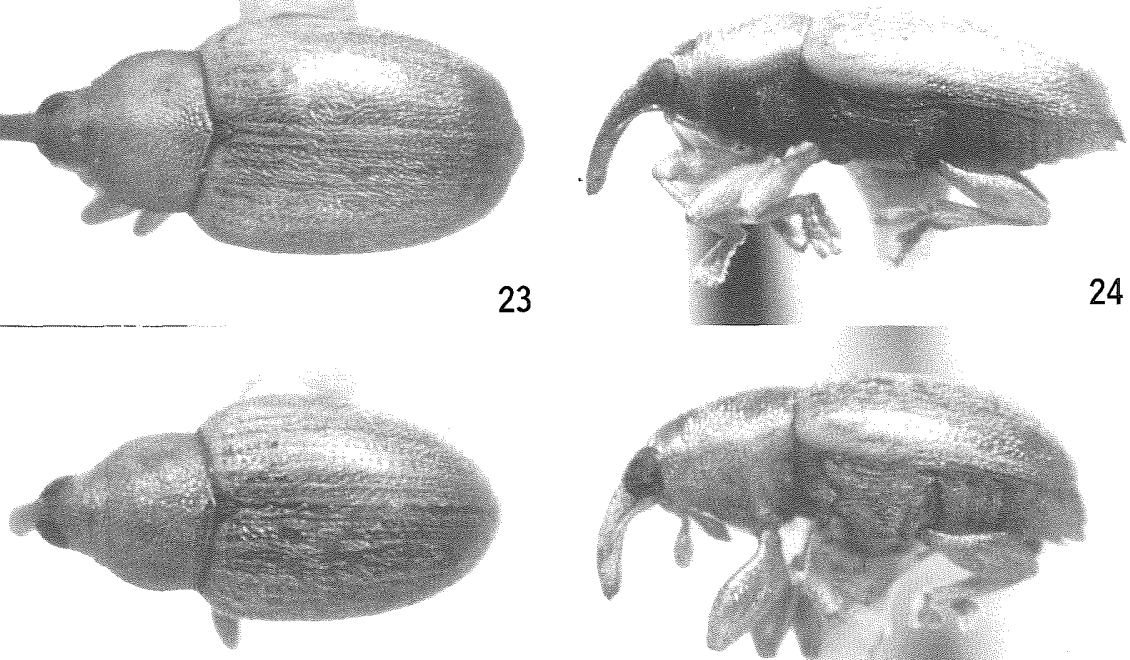

25
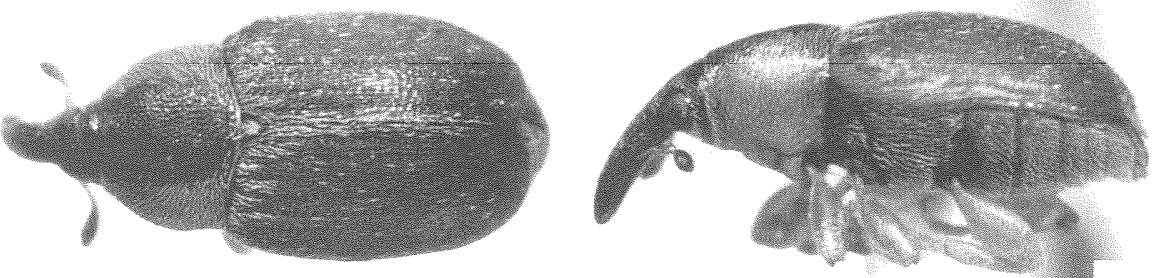

27

Figs. 23-28. Habitus photos of Acalyptini: 23, 24. Parimera flava; 25, 26. $P$. subflava; 27, 28. Imera formosana.

morphological features as noted in the key. Thus, we resurrect Orsophagus as a full genus (stat. rev.) in Acalyptini and placed it near Acalyptus.

Imera was established by Pascoe (1885) for I. pedestris Pascoe (Figs. 3-4) from Kandari (Celebes) in Anthonominae, and was synonymized with Amorphoidea by Marshall (1926). But, the structures of the antennal scrobe and the tarsal claws are different from the typical species of Amorphoidea. Thus, Imera is resurrected as a full genus (stat. rev.) in Acalyptini and placed near Amorphoidea.

Following genera now assigned in Derelomini are transferred to Acalyptini based on the characters mentioned above in the redefinition.

Zimmerman (1994) established Eudelodes for Amorphoidea bicolor Faust on its simple, edentate fore femora and its ninth elytral striae visible dorsally by comparing it with Eudela 

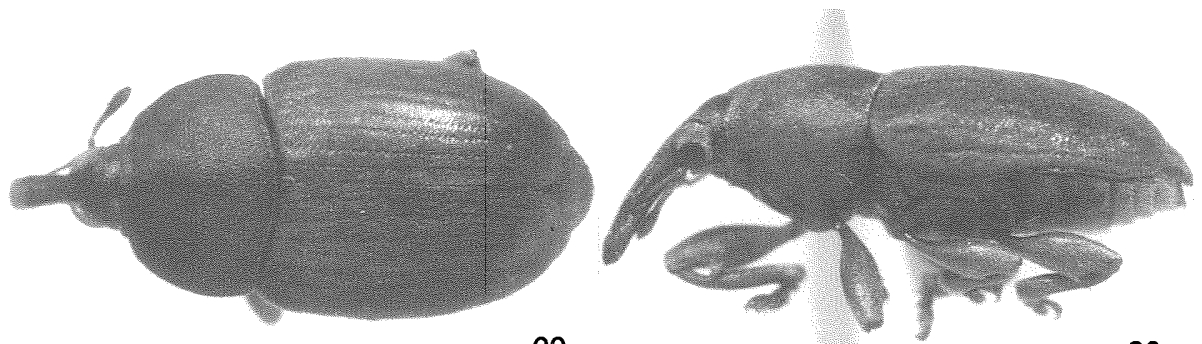

29

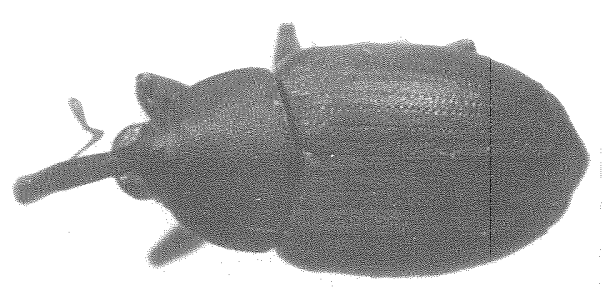

31

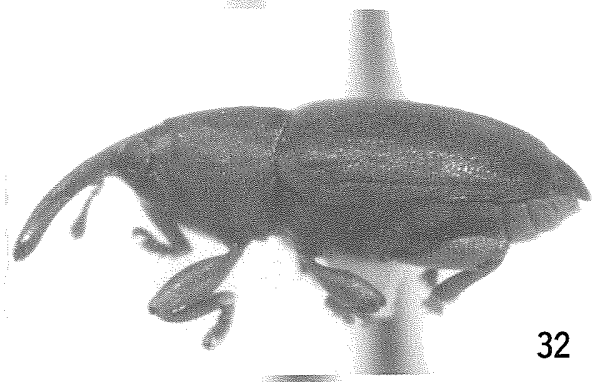

32
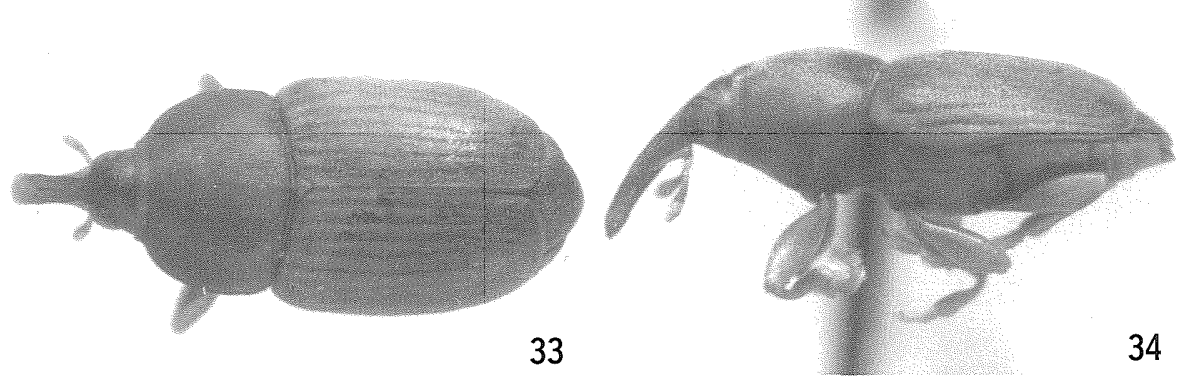

Figs. 29-34. Habitus photos of Amorphoidea lata: 29, 30. dark brown form, male; 31, 32. ditto, female; 33, 34. light brownish form, male.

Pascoe. But, the type species of Eudela is rather distinct (see below). Alonso-Zarazaga \& Lyal (1999) treated Eudelodes with Eudela in Curculioninae incertae sedis. Eudelodes is very similar to Amorphoidea, especially to A. pectoralis Marshall from Java in having a lateral tooth on the prothorax in the male (Marshall, 1937b), and is different only in the edentate fore femora, whereas the fore femora are at least obsoletely toothed in Amorphoidea and is classified in Acalyptini (new tribal assignment).

Eudela was established by Pascoe (1885) for E. rufescens Pascoe (Figs. 1-2) from Sarawak in Tychiinae. Klima (1934) treated Eudela in the genera incertae sedis of Erirhininae. Recently, Zimmerman $(1992,1994)$ transferred Eudela from Erirhininae to Curculioninae and placed it in Derelomini. Eudela is similar to Niseida, Parimera and Amorphoidea and placed here in Acalyptini (new tribal assignment). The type species of 
Eudela has the characteristic prothorax, which is strongly dilated laterally, nearly as wide as the elytra and abruptly constricted at subapical part. Lea (1915) added three species from Australia: E. atra, E. castanea and E. flavipennis. Among them E. castanea and E. flavipennis were transferred to Amorphoidea and Epamoebus Blackburn, respectively, by Zimmerman $(1992,1994)$. However E. castanea is neither a member of Amorphoidea nor Acalyptini because of the 6-segmented funicle and the structure of the abdominal ventrites. The type (female) of E. atra is very similar to Eudelodes bicolor and is a member of Eudelodes (comb. nov.). Thus, Eudela is restricted to the type species.

Tithene was established by Pascoe (1874) for T. microcephala Pascoe (Figs. 5, 6) from Sarawak in Erirhininae. Klima (1934) treated Tithene in Eugnomini of Erirhininae. Cawthra (1966) removed Tithene from Eugnominae and placed in ?Trypetini. Tithene was classified in Trypetinae and then transferred to Petalochilinae together with Parimera by Voss (1937, 1940, 1961). Alonso-Zarazaga \& Lyal (1999) classified Tithene in Derelomini, Curculioninae. Tithene is so similar to Parimera as to have been confused with the latter and should be classified in Acalyptini (new tribal assigmment). Voss (1940) erected the subgenus Hypotithene for T. barbirostris Voss from S. Celebes based on the edentate femora and the rostrum with dense hairs before the antennal insertion.

Derelomorphus was erected by Marshall (1928) for D. eburneus Marshall (Figs. 13, 14) from Malay Peninsula in Erirhininae and placed near Derelomus. Klima (1934) assigned this in Derelomini, Erirhininae. As the prothorax is not carinate laterally, the tergite 7 is exposed, and the tibiae are not mucronate at the tip, Derelomorphus is transferred from Derelomini to Acalyptini (new tribal assignment). Ramamurthy \& Ghai (1989) described the second species, D. subfulvus, from India, but it is a member of Amorphoidea and very similar to Amorphoidea arcuata. Derelomorphus eburneus is associated with the staminate flowers of Cocos nucifera (Marshall, 1928; Lepesme, 1947).

Nodocnemus was established by Marshall (1931) for N. subfasciatus Marshall from Samoa and N. uniformis (Figs. 9, 10) was described by him (1937) from New Hebrides. Nodocnemus was at first placed in Derelomini, Erirhininae, and this treatment was followed by Klima (1934). Lepesme (1947) assigned Nodocnemus to Erirhininae, and separated from Derelominae. As the tergite 7 is broadly exposed and the tibiae do not have a mucro at the tip, Nodocnemus is assigned to Acalyptini (new triball assignment). These species are associated with palms, and the host plant of $N$. uniformis is confirmed to be Cocos nucifera (Lepesme, 1947).

A monotypic genus Meredolus was erected by Marshall (1935) for M. cocotis Marshall (Figs. 11, 12) from Solomon Is. and placed in Derelominae. This treatment was followed by Lepesme (1947). As Meredolus was compared with his genera Nodocnemus and Derelomorphus by Marshall (1935), it is similar to them in having the exposed tergite 7. Thus, Meredolus is transferred from Derelominae (or Derelomini) to Acalyptini (new tribal 


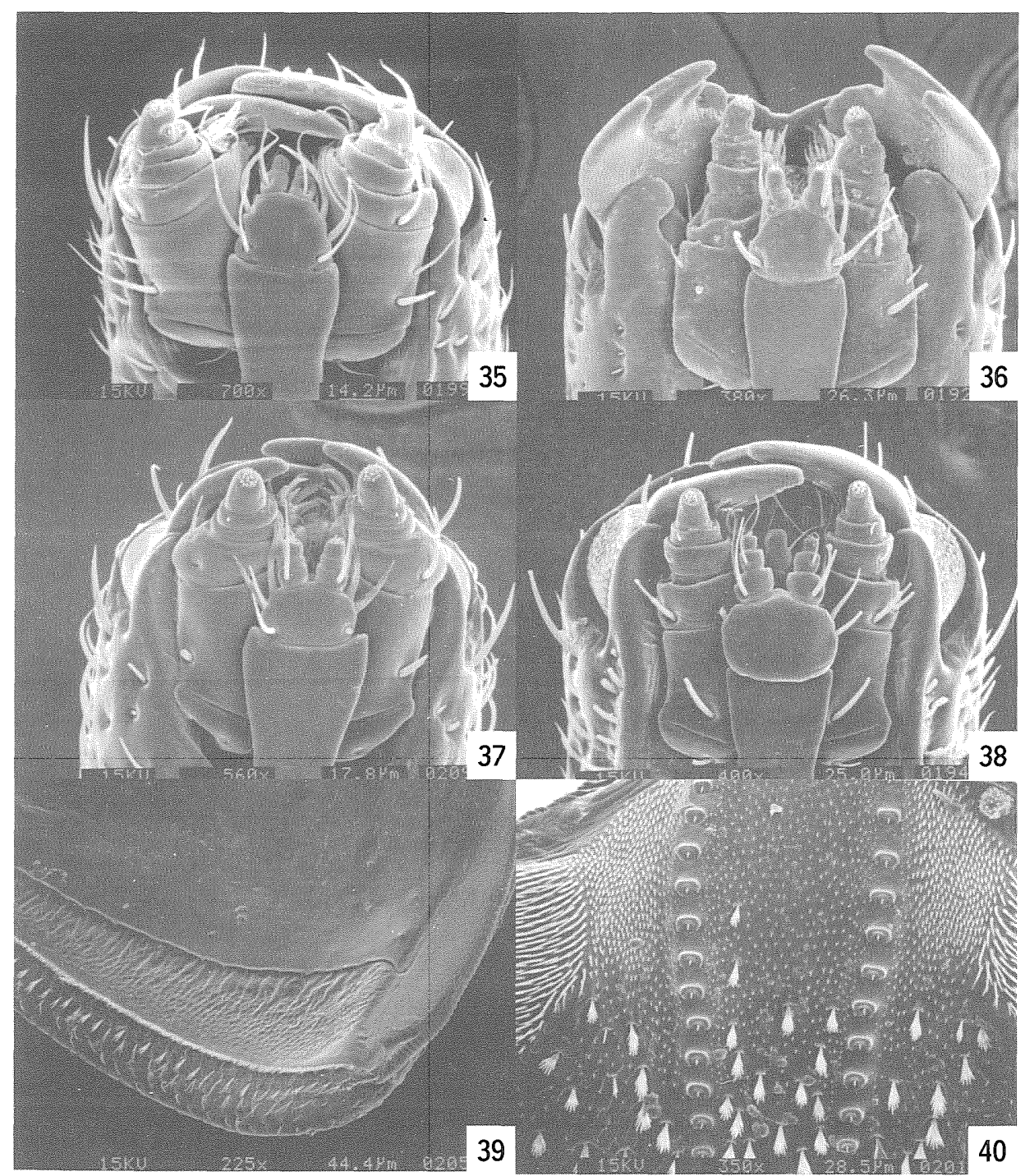

Figs. 35-40. Mouth parts of Acalyptini and Derelomini and elytro-tergal stridulatory organ of Derelomini: 35. Parimera flava; 36. Amorphoidea lata; 37. Orsophagus trifasciatus; 38-40. Derelomus uenoi. 35-38. mouth parts, ventral view; 39, apex of right elytron, internal view; 40 . setiferous tubercles of tergite 7.

assignment).

As a result, Derelomini is restricted to the genera Derelomus and Elaeidobius, which is introduced from Africa in Asia-Pacific region. Taxonomic changes are summarized as follows (Table 1). 

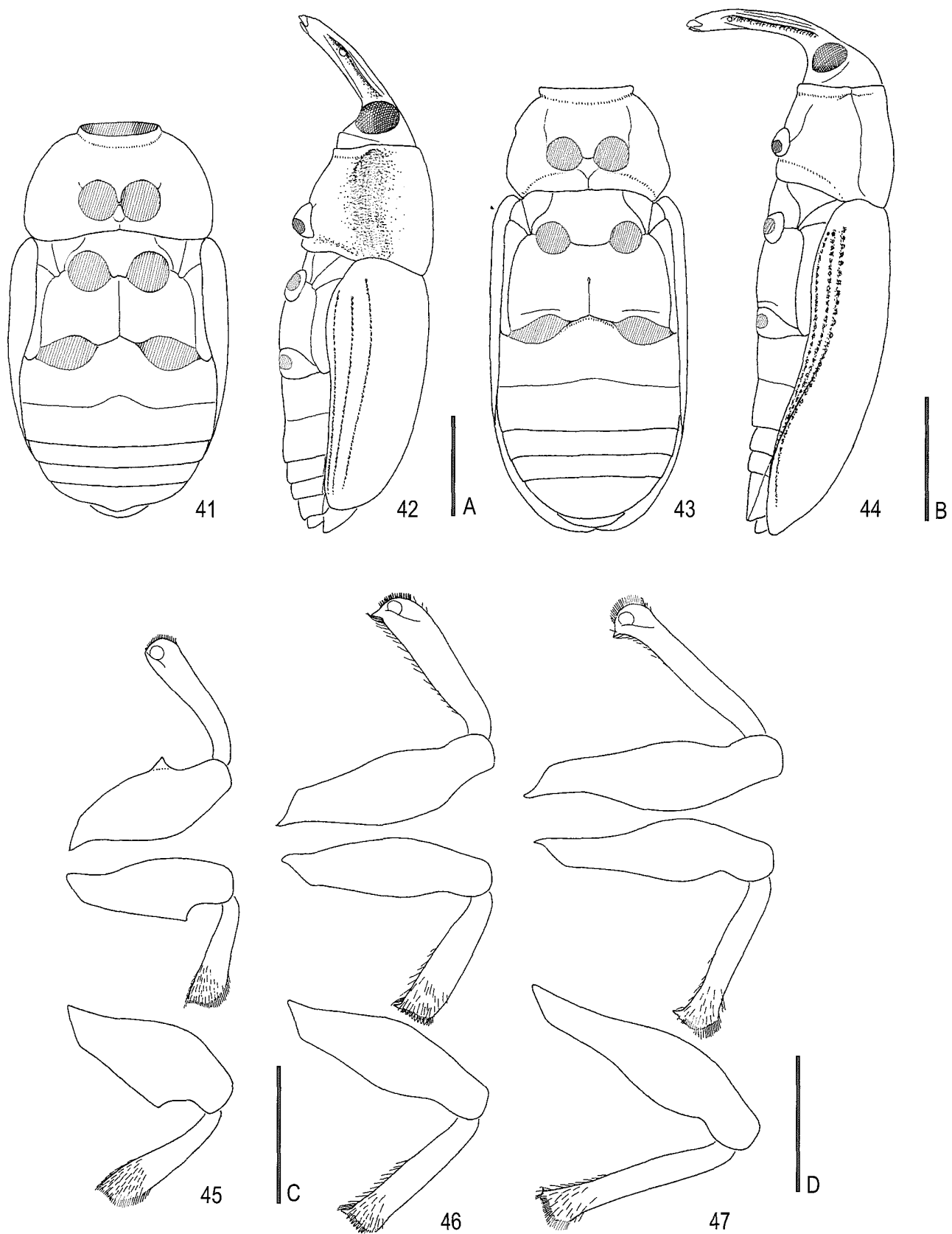

Figs. 41-47. Ventral and lateral views and legs of Acalyptini and Derelomini: 41, 42. Amorphoidea lata, male; 43, 44. Derelomus uenoi, male; 45. Imera formosana; 46. Elaeidobius kamerunicus; 47. Derelomus uenoi. Scales A, B=1.0mm (bar A for figs. 41, 42, bar B for figs. 43, 44); Scale $C=0.5 \mathrm{~mm}$ (for fig. 45); Scale $\mathrm{D}=0.25 \mathrm{~mm}$ (for figs. 46, 47). 
Table 1. Comparison of classification system of Acalyptini/Derelomini in Asia-Pacific region.

\begin{tabular}{cc}
\hline Previous system & Present system \\
\hline Curculioninae & Curculioninae \\
Acalyptini & Acalyptini \\
Acalyptus Schoenherr & Acalyptus Schoenherr \\
=Orsophagus Roelofs & Orsophagus Roelofs, stat. rev. \\
Amorphoidea Motschulsky & Amorphoidea Motschulsky \\
$=$ Imera Pascoe & $=$ Ecthetophyga Pierce \\
$=$ Ecthetophyga Pierce & Imera Pascoe, stat. rev. \\
Parimera Faust & Parimera Faust \\
Niseida Pascoe & Niseida Pascoe \\
Derelomini & Eudela Pascoe \\
Eudela Pascoe & Eudelodes Zimmerman \\
Eudelodes Zimmerman & Derelomorphus Marshall \\
Derelomorphus Marshall & Nodocnemus Marshall \\
Nodocnemus Marshall & Meredolus Marshall \\
Meredolus Marshall & Tithene Pascoe \\
Tithene Pascoe & Derelomini \\
Derelomus Schoenherr & Derelomus Schoenherr \\
Elaeidobius Kuschel & Elaeidobius Kuschel \\
\hline
\end{tabular}

\section{Key to genera}

1 (10) : Femora edentate. Procoxae narrowly distant.

2( 9): Tarsal claws at most obsoletely toothed at base.

3 ( 6) : Prothorax widest at base, thence curved and narrowed to weak subapical constriction. Rostrum with antennal scrobe running to lower half of rostrum.

4 ( 5) : Prothorax nearly rectangular at posterior angles. Prosternum with vertical concave process in front of and between fore coxae in large male. Integument pale yellow, very thinly pubescent. Melanesia (Solomon Is.). Meredolus Marshall

5 ( 4) : Prothorax sharply acute at posterior angles. Prosternum without process before coxae. Integument black, pubescent. Polynesia (Samoa), Melanesia (New Hebrides I.). Nodocnemus Marshall

6( 3) : Prothorax rounded laterally, widest around middle or subparallel-sided near base.

7 ( 8) : Prothorax rounded laterally. Integument thinly pubescent. Rostrum with antennal scrobe running to lower half of eye. Indonesia (Aru). Niseida Pascoe

8( 7) : Prothorax subparallel-sided on basal half or often widening from base to middle. 

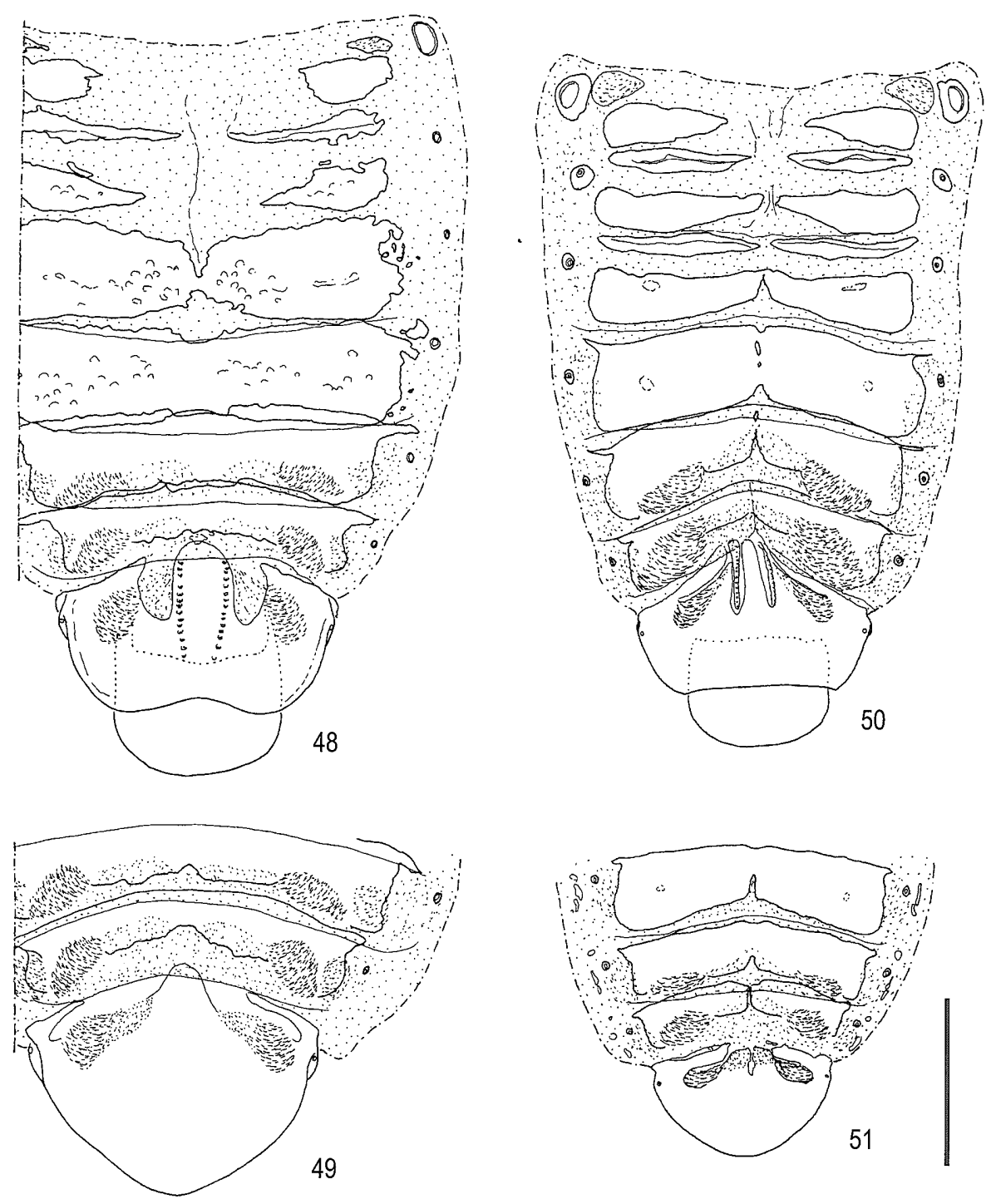

Figs. 48-51. Tergites of Derelomini: 48. Derelomus uenoi, male; 49. ditto, female; 50. Elaeidobius kamerunicus; 51. ditto, female. Scale $=0.5 \mathrm{~mm}$.

Integument pubescent. Rostrum with dorsal carinae of antennal scrobe running to median part of eye. Palearctic region. Acalyptus Schoenherr

9( 2) : Tarsal claws distinctly toothed at base. Integument with scale-like setae forming maculation on dorsum. Palearctic (Japan and Korea) and Oriental regions. Orsophagus Roelofs

10 ( 1) : Femora dentate at least on hind or fore pair, rarely denticle obsolete. If femora 
edentate, then procoxae distant widely from each other (Tithene) or in male 5th ventrite longer than 3rd and 4th ventrites combined (Parimera).

11 (12) : Tergite 7 narrowly exposed from apices of elytra. Aedeagus without setae at apex; inner sac simple. Integument pale yellow, very thinly pubescent. Malay Peninsula.

Derelomorphus Marshall

12(11) : Tergite 7 broadly exposed from apices of elytra.

13 (14) : Prothorax strongly dilated laterally, nearly as wide as elytra, abruptly curved and narrowed to weak subapical constriction at sides. Elytra widest behind shoulders. Borneo (Sarawak).

Eudela Pascoe

14 (13) : Prothorax moderately dilated laterally, narrower than elytra, weakly curved and narrowing to subapical constriction. Elytra subparallel-sided behind shoulders or weakly rounded laterally.

15 (22) : Hind femoral tooth usually greater than those of fore and middle pairs or nearly as great as those of fore pair. Rostrum shorter than head and pronotum combined, not dentate on apical half dorsally and fore tibiae and tarsi without long hairs along inner margin in male. Procoxae narrowly distant, by less than width of rostrum.

16(21) : Rostrum with dorsal carina of antennal scrobe definite or sharply defined; dorsum weakly carinate at least in male. Tarsal claws usually toothed at base. Venter weakly convex ventrally, 5th ventrite shorter than 3rd and 4th ventrites combined.

17(20) : Eyes convex. Rostrum with dorsal carina of antennal scrobe leaving antennal socket visible laterally. Tarsal claws widely diverged.

18(19) : Fore femora edentate. New Guinea, Australia. Eudelodes Zimmerman

19(18) : Fore femora dentate. Oriental region. Amorphoidea Motschulsky

20(17) : Eyes weakly convex. Rostrum with dorsal carina of antennal scrobe almost concealing antennal socket beneath it. Tarsal claws moderately diverged. Oriental region.

Imera Pascoe

21 (16) : Rostrum with dorsal carina of antennal scrobe weakly defined; dorsum without carina. Tarsal claws toothed minutely to obsoletely at base. Venter arcuately convex ventrally, 5th ventrite longer than 3 rd and 4 th ventrites combined in male. Oriental region. Parimera Faust

22 (15) : Femora toothed at least in fore pair, teeth greater than those of middle and hind pairs except $T$. vitticollis Heller and $T$. barbirostris Voss, with edentate femora. Rostrum usually slender, longer than head and pronotum combined, dentate on apical half dorsally and fore tibiae and tarsi with long hairs along inner margin in male. Procoxae usually distant widely, distance as wide as or wider than width of rostrum. Oriental region. Tithene Pascoe 

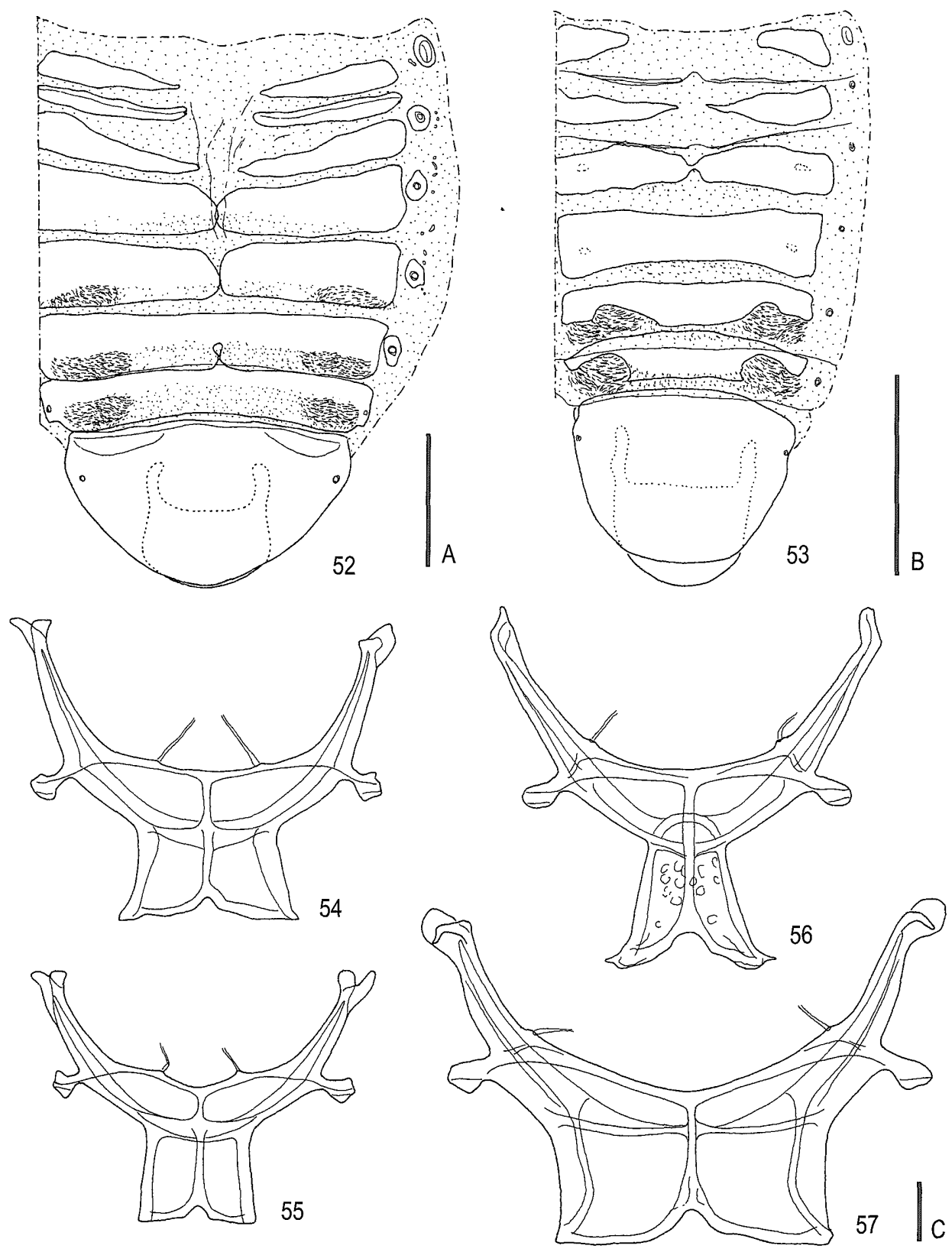

Figs. 52-57. Tergites and metendosternites of Acalyptini and Derelomini: 52. Amorphoidea lata; 53. Orsophagus trifasciatus; 54. Acalyptus carpini; 55. Parimera flava; 56. Elaeidobius kamerunicus; 57. Derelomus uenoi. 52, 53. tergites, male; 54-57. metendosternites. Scales A, B=0.5 mm (bar A for fig. 52, bar B for fig. 53); Scale $C=0.1 \mathrm{~mm}$ (for figs. 54-57). 
86

H. KOJIMA \& K. MORIMOTO
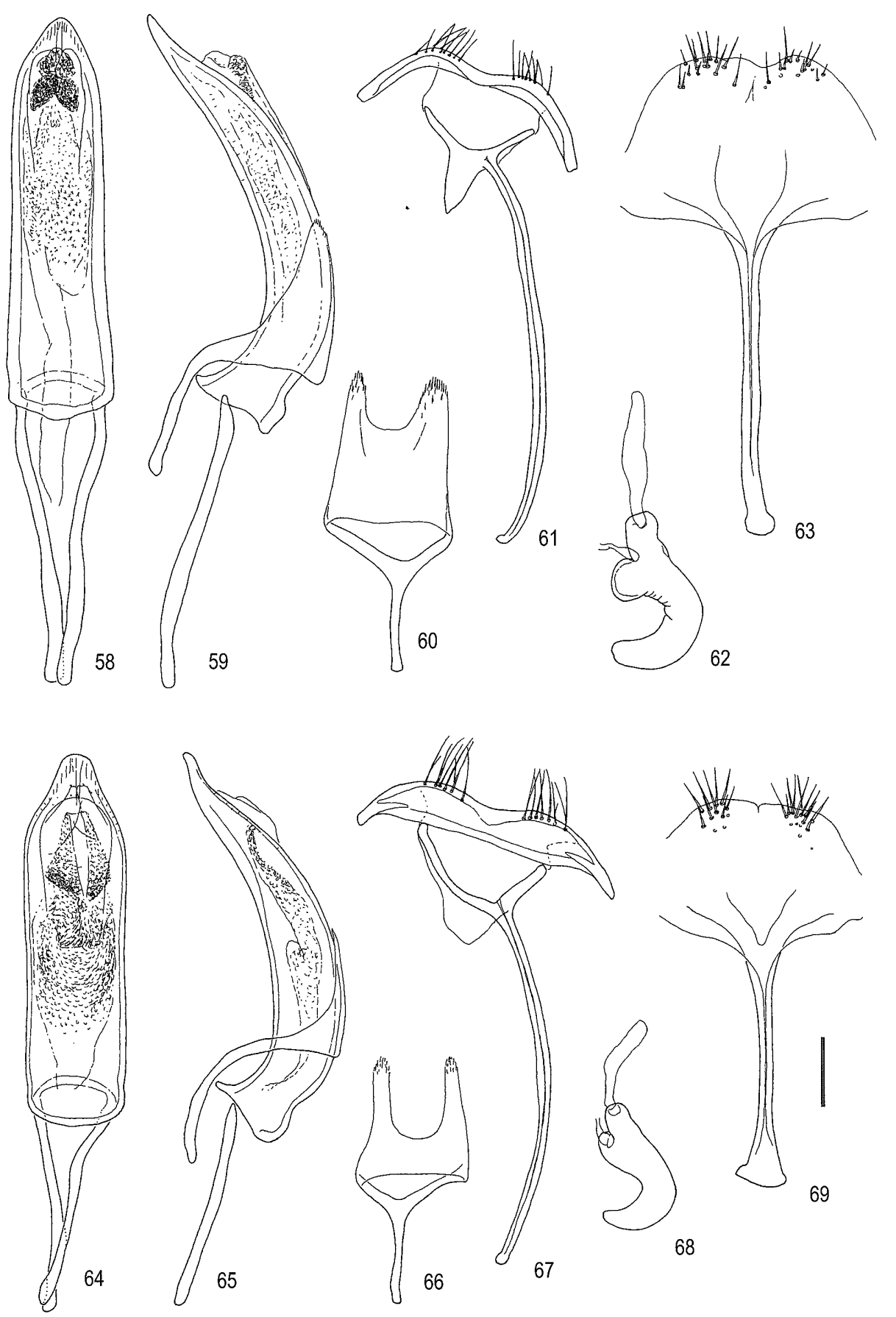

Figs. 58-69. Male and female genitalia of Derelomini. 58-63. Derelomus uenoi; 64-69. D. bicarinatus; 58,64 . aedeagus, dorsal; 59, 65. ditto, lateral; 60, 66. tegmen; 61, 67. sternite 8 and spiculum gastrale, male. 62,68 . spermatheca; 63,69 . sternite 8 , female. Scale $=0.1 \mathrm{~mm}$. 

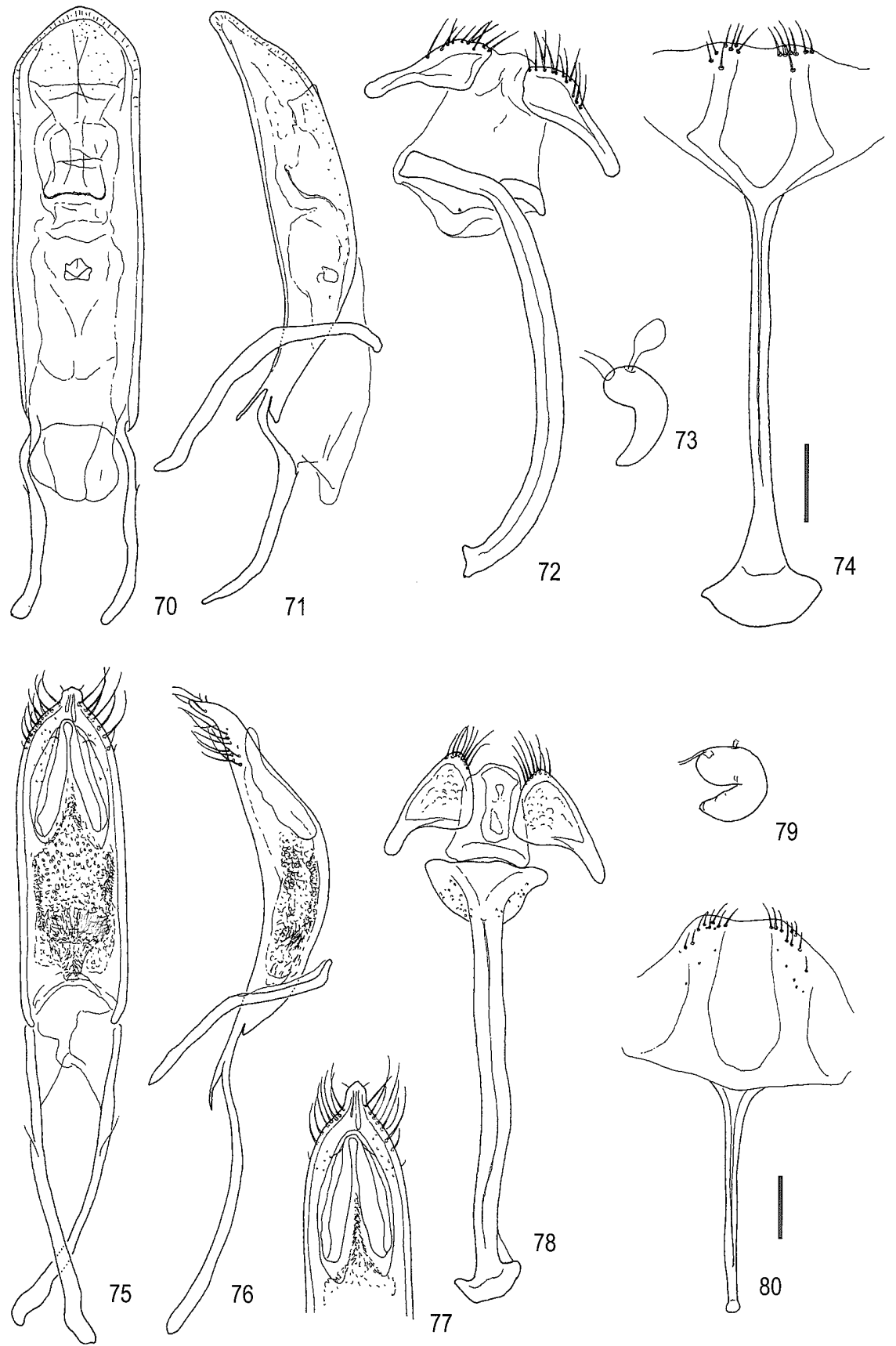

79

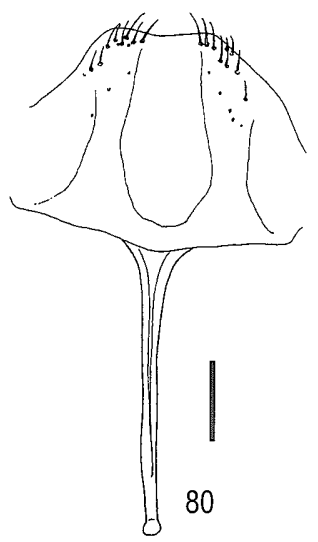

Figs. 70-80. Male and female genitalia of Derelomini and Acalyptini: 70-74. Elaeidobius kamerunicus; 75-80. Imera formosana; 70, 75. aedeagus, dorsal; 71, 76. ditto, lateral; 77. apex of aedeagus; 72, 78. sternite 8 and spiculum gastrale; 73, 79. spermatheca; 74, 80 . sternite 8 , female. Scale $=0.1 \mathrm{~mm}$. 


\section{Biology}

Acalyptini feed on a wide range of inflorescences of Salicaceae, Meliaceae, Malvaceae and Arecaceae. The adults are found on the flowers of their hosts, and the eggs are laid in the tissue of the blooming flowers, into the sheath of the ovary or the staminal column. The larvae feed on their way into the ovary. The mature larvae leave their hosts, and pupate in the soil.

As large numbers of adults are often attracted to the flowers, some of them are known as pests. Member of Amorphoidea and Eudelodes infest Malvaceae, and the followings are known as pests of cotton in cultivated areas: A. lata Motschulsky [Philippines]; A. rufa Hustache [Indochina]; A. arcuata Motschulsky [India]; A. subfluvus (Ramamurthy \& Ghai) [India and Sri Lanka]; A. pectoralis Marshall [Indonesia: Java], and E. basalis (Faust) [New Guinea and Australia].

On the other hand, some taxa are associated with palms and may be involved in pollination. The followings are know to be attracted to the flowers of coconut palm: Derelomorphus eburneus Marshall [Malaysia and Singapore]; Meredolus cocotis Marshall [Solomon Is.]; Nodocnemus uniformis Marshall [New Hebrides], and Amorphoidea (?) coimbatorensis Subramanian [S. India]. Derelomorphus eburneus is apparently restricted to coconut flowers, and may be an important pollinator (Cock, 1985). Also, Parimera palmarum Voss found on a certain palm of seashore (Voss, 1940), P. trivittata Heller on Pinanga sp. (Heller, 1915), P. fusca Voss on 'Salak' fruit (Voss, 1961), and Nodocnemus subfasciatus Marshall on the flowers of native palm (Marshall, 1931).

\section{Distribution}

Most genera are known to occur in the Oriental and Australian regions including the Polynesian subregions except New Zealand, and some are known from the Palearctic region. None of them has ever been known from the Ethiopian and Nearctic regions, except one species, Acalyptus carpini, introduced from the Palearctic region into the Nearctic.

As all the members previously assinged in Derelomini are transferred to Acalyptini in the Malesia, Pacific islands and Australia, weevils known to be associated with palm flowers are not belonging to Derelomini as it has generally been recognized, but are to Acalyptini.

\section{Systematic position}

As mentioned in the introduction, Acalyptini have been placed in Erirhininae (Klima, 1934) or Anthonominae (Voss, 1953, 1958), or treated independently as Acalyptinae (Marshall, 1937; Morimoto, 1962), and some genera were described in Derelominae (-ni), Trypetinae or 
Petalochilinae. Recently, Zherikhin \& Egorov (1990), Egorov et al., (1996) and AlonsoZarazaga \& Lyal (1999) placed Acalyptini within Curculioninae, which have been expanded by Kuschel (1992) to include Anthonominae, Rhamphinae, Tychiinae, and others. Zimmerman (1994) also defined Curculioninae in a broad sense and included Derelomini, but all of the Australian genera he classified in Derelomini are transferred here to Acalyptini. As the members of Acalyptini have often been assigned to Derelomini, these tribes superficially resemble each other especially in the genera associated with palms supposedly due to convergence. The tribe Acalyptini is also similar to the southern Gondwanian tribe Eugnomini in having the unarmed tibiae at the tip and the widely divergent, free tarsal claws. Thus, we treat Acalyptini in Curculioninae, tentatively following recent authors, although the monophyly of this subfamily is not confirmed at present.

\section{Taxonomic treatment of the Japanese, Korean and Taiwanese species, with brief review of genera}

\section{Tribe Acalyptini Thomson}

Acalyptina Thomson, 1859: 143 (part).

Acalyptini Bedel, 1884a: 68. -Bedel, 1884b: 121. -Klima, 1934: 138 (catalogue, Erirhininae). Voss, 1953: 61 (Anthonominae). -Hoffmann, 1954: 678, 1126 (Calandrinae). -Voss, 1958: 113 (Anthonominae). -Lohse, 1983: 79 (Curculioninae). -Zherikhin \& Egorov, 1990: 117 (Curculioninae). -Alonso-Zarazaga \& Lyal, 1999: 73 (catalogue, Curculioninae). Acalyptinae Aurivillius, 1920: 38. -Marshall, 1937b: 473. -Morimoto, 1962a: 341 (checklist of Japanese species). -Morimoto, 1962c: 39, 55 (key to Japanese genera).

See Klima (1934) for other references.

\section{Genus Acalyptus Schoenherr}

Acalyptus Schoenherr, 1833: 20. -Klima, 1934: 138 (Erirhininae). -Nyholm, 1952: 219 (figures of aedeagus \& antennae of Swedish Acalyptus species). -Hoffmann, 1954: 1126. Morimoto, 1962a: 341. -Morimoto, 1962c: 39, 55 (Acalyptinae). -Kissinger, 1964: 45, 47 (Erirhininae: Derelomini). -O’Brien \& Wibmer, 1982: 96 (Erirhininae: Derelomini). Lohse, 1983: 79 (Curculioninae). -Dieckmann, 1988: 374 (Curculioninae). -Egorov et al., 1996: 484 (Curculioninae). -Alonso-Zarazaga \& Lyal, 1999: 73.

See Klima (1934) for other references.

Integument with scale-like setae not maculate. Antennae with funicle 7-segmented. Rostrum not carinate dorsally; antennal scrobe with dorsal carina running to median part of eye. Femora edentate. Tarsal claws widely diverged, not toothed at base. Procoxae narrowly distant. Ventrites weakly convex ventrally, 5th ventrite shorter than 3 rd and 4th ventrites 


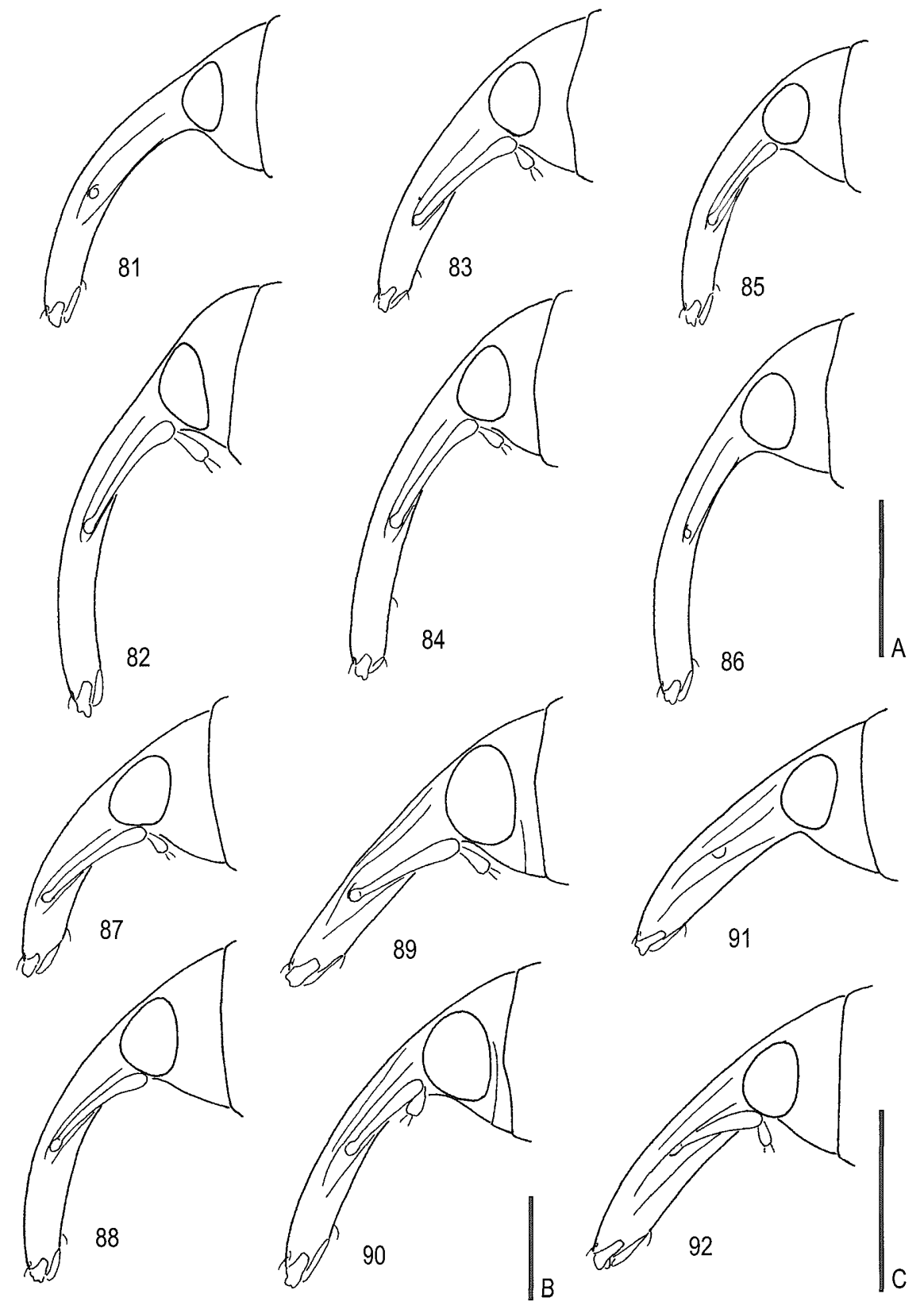

Figs. 81-92. Heads, lateral views of Acalyptini: 81. Acalyptus carpini, male; 82. ditto, female; 83. Orsophagus trifasciatus, male; 84. ditto, female; 85. O. subfasciatus, male; 86 . ditto, female; 87. Parimera flava, male; 88. ditto, female; 89. Amorphoidea lata, male; 90. ditto, female; 91 . Imera formosana, male; 92 . ditto, female. Scale $=0.5 \mathrm{~mm}$ (bar A for figs. $81-86$, bar B for figs. 87-90, bar C for figs. 91, 92) 


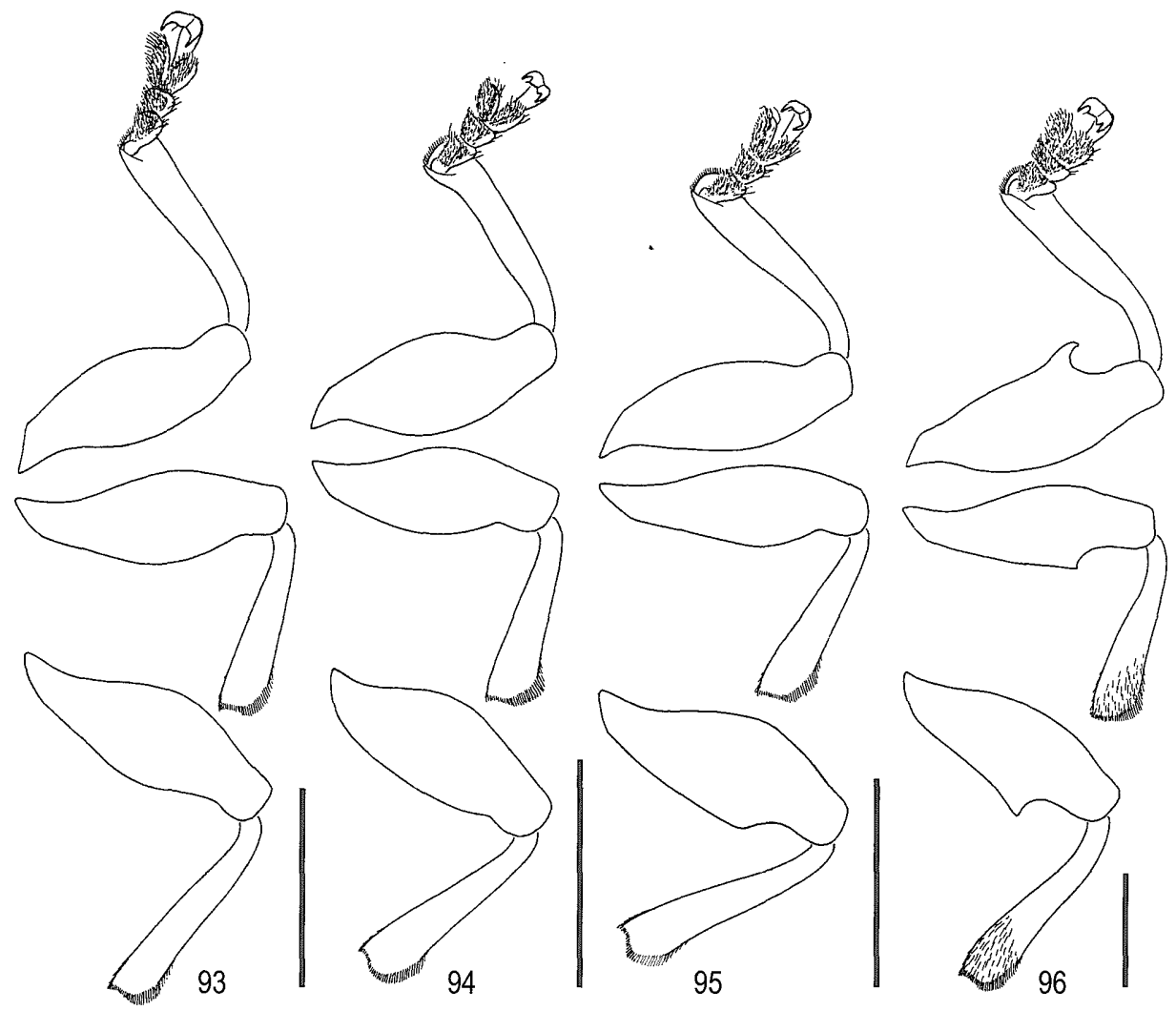

Figs. 93-96. Legs of Acalyptini: 93. Acalyptus carpini; 94. Orsophagus trifasciatus; 95. Parimera flava; 96. Amorphoidea lata. Scale $=0.5 \mathrm{~mm}$.

combined. Tergite 7 obliquely exposed; tergite 8 (male) transverse. Aedeagus produced in middle at apex, with short setae on each side, with a transverse orificial sclerite; inner sac densely and finely asperate around gonopore.

Acalyptus is associated with Salix spp. of Salicaceae, the larvae grow in the flower catkin and pupate in the ground.

Distribution. Palearctic region. One species, A. carpini was introduced into North America, and two doubtful species in their position are knwon from the Oriental region.

Comments. Two species, Acalyptus sabulicolor Motschulsky, 1866 from Ceylon and A. fasciatus Voss, 1968 from Tonkin are unknown to us, but $A$. fasciatus may not be congeneric because of the toothed tarsal claws and the maculate integument by the scale-like setae according to the original description, and the description of $A$. sabulicolor is too brief. 


\section{Acalyptus carpini (Fabricius)}

(Figs. 17, 18, 54, 81, 82, 93, 97-101)

Curculio carpini Fabricius, 1792: 409.

Acalyptus carpini: Klima, 1934: 139. -Nyholm, 1952: 223. -Hoffmann, 1954: 1127. Morimoto, 1962a: 341 (Japan: Hokkaido; Siberia, Europe). -Nakane, 1963: 378, pl. 189, fig. 22 (Japan: Honshu; Siberia, Europe). -Krivolutskaya et al., 1978: 96 (Acalyptinae). Morimoto, 1984: 298, pl. 58, fig. 26. -Kwon \& Lee, 1986: 85 (Korea; Japan: Hokkaido, Honshu; Siberia; Europe). -Dieckmann, 1988: 375. -Egorov et al., 1996: 484 (Curculioninae). -Hong et al., 2000: 39, fig. 44.

Acalyptus fuscipes Thomson, 1870: 337. -Nyholm, 1952: 224 (=A. carpini)

See Klima (1934) for other synonymy.

Redescription. Male. Length: 1.8-2.6 mm. Integument with variation in color. Reddish brown, head, rostrum, pronotum, scutellum, underside usually except ventrites, and often elytra along suture and basal part dark brown to black, or entirely black, except reddish brown antennae and tarsi; clothed with yellowish grey with silky shine to silvery recumbent scalelike setae.

Forehead between eyes slightly narrower than base of rostrum. Eyes hardly convex. Rostrum longer than pronotum (6:5), evenly curved; dorsum subconfluently punctate, without carina. Antennae inserted just a little before middle of rostrum; scape slightly longer than length of funicle; funicle with 1 st segment 2.5 times as long as broad, 2 nd less than half as long as 1 st, 3 rd to 7 th subequal in length, $2 / 3$ times as long as 2 nd, weakly widening apically, 7th a little broader than long; club as long as basal three segments of funicle combined.

Prothorax 1.3 times as wide as long, subparallel-sided on basal half or weakly widening from base to middle, thence weakly curved and narrowing to weak subapical constriction. Scutellum subtriangular, thinly clothed with setae. Elytra 1.3 times as long as wide, very weakly rounded laterally, widest at middle; intervals evenly with recumbent scale-like setae except 1st interval, in which the setae are often slightly denser than the others.

Venter with basal two ventrites depressed in middle.

Female. Resembles male except 2.3-2.7 mm in length; rostrum nearly as long as head and pronotum combined; antennae inserted in or just a little behind middle of rostrum and venter with basal two ventrites flattened in middle.

Specimens examined. Japan: Hokkaido. Osappe, Lake Kuccharo, 1 ex., 5. vi. 1957, M. Takahashi. Nibushi, Lake Kuccharo, 1 ex., 7. vi. 1957, M. Takahashi. Tokachi, Ashoro, 1 ex., 30. vii. 1949, R. Matsuda; 1 ex., 31. v. 1957, M. Takahashi; 4 exs., 24-31. vii. 1959, K. Morimoto. Lake Tofutsu, Abashiri, 1 ex., 12. viii. 1989, H. Kojima. Kaminokuni-machi, Matsumae-hanto, 2 exs., 24. vii. 1990, H. Kojima. Mt. Rishirisan, Rishiri Is., 1 ex., 4. viii. 1990, T. Kishimoto. Japan: Honshu. Kuromori-pass, Rokugo-machi, Akita Pref., 2 exs., 7. 
vi. 1978, K. Baba \& N. Kato. Momoyake, Chokai-mura, Akita Pref., 4 exs., 16. v. 1978, K. Baba. Mt. Tegata, Akita Pref., 2 exs., 20. v. 1987, H. Kikuchi. Atsumi-spa, Yamagata Pref., 1 ex., 18. vii. 1977, K. Baba. Mt. Hakusan, Ishikawa Pref., 1 ex, 31. vii. 1956, Y. Murakami. Mt. Houryu, Suzu, Ishikawa Pref., 1 ex., 6. v. 1978, T. Mikage. Sasaguchihama, Niigata Pref., 4 exs., 19. v. 1961, K. Baba. Akadani, N-Echigo, 1 ex., 13. vi. 1976, K. Baba. Muroya, Kamikawa, N-Echigo, 2 exs., 11. vii. 1976, K. Baba. Kurokawa, N-Echigo, 7 exs., 23. iv. 1973, K. Baba; 4 exs., 19. iv. 1976, K. Baba. Budo-toge, N-Echigo, 4 exs., 14. iv. 1973, K. Baba. Mt. Shinbotake, N-Echigo, 2 exs., 25. v. 1972, K. Baba. Senami, N-Echigo, 3 exs., 28. iv. 1976, K. Baba. Tsugawa, N-Echigo, 2 exs., 8. v. 1976, K. Baba. Miomote, N-Echigo, 1 ex., 16. v. 1976, K. Baba. Mikuni-pass, M-Echigo, 2 exs., 19. v. 1976, K. Baba. Mt. Yahiko, M-Echigo, 1 ex., 19. v. 1976, K. Baba. Mt. Hishigatake, S-Echigo, 1 ex, 11. viii. 1970, K. Baba. Mimetani, Okutama, Tokyo, 3 exs., 7. v. 1982, K. Emoto. Kamitakara-mura, Gifu Pref., 2 exs., 7. iii. 1988, T. Nohira. Korea. Kwang Nung, Pocheon Gun, 1 ex., 14. vi. 1983, K. Morimoto; 6 exs., 16. v. 1984, K. Morimoto. Sam Jeong Li, Ma Cheong Meon, Hamyang Gun, Gyeong Sam Nam Do, 4 exs., 9. v. 1991, K. Morimoto. Mt. Tae Baek, Tae Baek Si, Kang Won Do, 1 ex., 12. viii. 1991, J. D. Bae; 1 ex., 13. viii. 1991, J. D. Bae; 3 exs., 14. viii. 1991, J. D. Bae. Boung Myung-ri, Dong San-myon, Chuchon-gun, 36 exs., 21. vii. 1992, K. Morimoto \& J. D. Bae.

Distribution. Japan (Hokkaido, Rishiri I., Honshu), Kuril Is., Sakhalin, Korea, China, Siberia, Europe, North America (introduced).

Biological note. Weevils were found on Salix caprea, S. cinerea, S. purpurea, S. incana, S. alba, S. viminalis and S. fragilis in Europe (Dieckmann, 1988). In Japan, adults were also found on Salix spp., but the species and host association have never been confirmed.

Comments. This species is very similar to A. sericeus Gyllenhal occurring in Europe and Siberia, and several keys distinguishing $A$. carpini from $A$. sericeus are available (ex. Nyholm, 1952, Hoffmann, 1954, Dieckmann, 1988).

\section{Genus Orsophagus Roelofs, stat. rev.}

Orsophagus Roelofs, 1874: 123 (type species: Orsophagus trifasciatus Roelofs, by monotypy; Erirhinides vrais). -Kôno, 1930: 160 (Erirhini). -Klima, 1934: 50 (Erirhininae). Morimoto, 1983: 54 (= Acalyptus). -Alonso-Zarazaga \& Lyal, 1999: 73.

Integument with scale-like setae maculate or fasciate. Antennae with funicle 7-segmented. Rostrum not carinate dorsally; antennal scrobe with dorsal carina running to middle or slightly lower than half of eye. Femora edentate. Tarsal claws widely diverged, toothed at base. Procoxae narrowly distant. Ventrites weakly convex ventrally, 5th ventrite shorter than 3rd and 4th ventrites combined. Tergite 7 obliquely exposed; tergite 8 (male) transverse. Aedeagus without conspicuous setae at apex, with a pair of orificial sclerites; inner sac simple. 

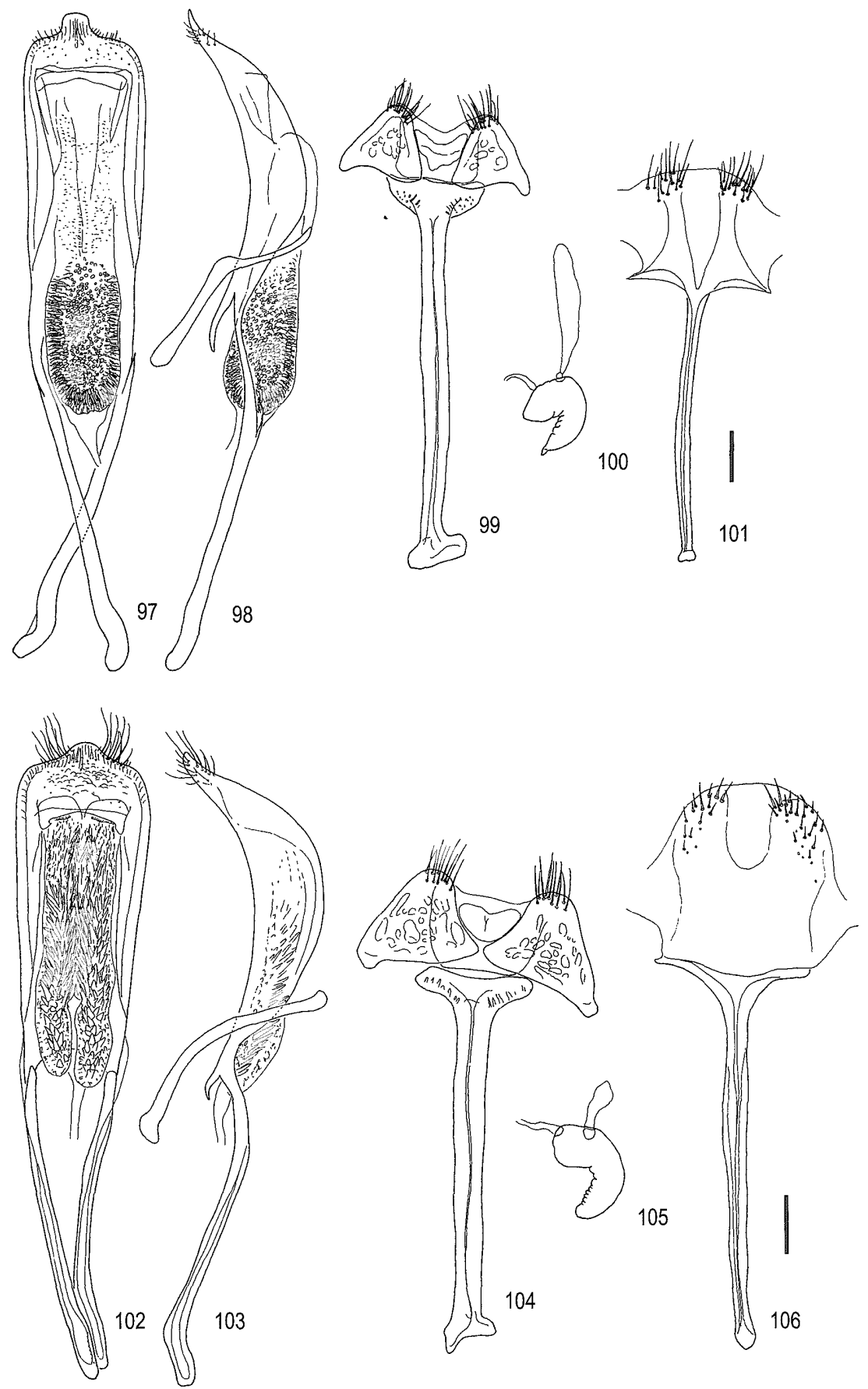

Figs. 97-106. Male and female genitalia of Acalyptini: 97-101. Acalyptus carpini; 102-106. Amorphoidea lata; 97, 102. aedeagus, dorsal; 98, 103. ditto, lateral; 99, 104. sternite 8 and spiculum gastrale; 100, 105. spermatheca; 101, 106. sternite 8, female. Scale $=0.1 \mathrm{~mm}$. 
Orsophagus is known to be associated with Melia of Melicaceae.

Distribution. Palearctic (Manchurian subregion) and Oriental regions.

Comments. Morimoto (1983) synonymized this genus with Acalyptus Schoenherr, but Orsophagus is distinguished from Acalyptus by the toothed tarsal claws and the fasciated integument by the scale-like setae externally. Two undescribed species from Sabah, East Malaysia and Sulawesi are in our collection.

\section{Orsophagus trifasciatus Roelofs}

(Figs. 19, 20, 37, 53, 83, 84, 94, 107-112)

Orsophagus trifasciatus Roelofs, 1874: 124. -Kôno, 1930: 161.

Acalyptus trifasciatus: Morimoto, 1983: 54 (Japan: Shikoku, Kyushu). -Morimoto, 1984.

298, pl. 58, fig. 25. -Kwon \& Lee, 1986: 85 (Korea: Chejudo; Japan). -Hong et al., 2000: 40, fig. 45.

Redescription. Male. Length: 2.1-2.3 mm. Integument reddish to dark reddish brown, antennae and legs paler, underside usually darker; clothed with recumbent yellowish grey scalelike setae with silky shine, pronotum and elytra mixed with dark brown scale-like setae forming maculation as follows: pronotum with longitudinal dark stripe along midline and a dark faint fleck on each side at middle, elytra with subbasal dark flecks on 3rd and 5th to 6th intervals, and postmedian and subapical dark transverse bands, which are continuous on 1st interval, subbasal flecks often indefinite on 3rd interval or continuous from $2 \mathrm{nd}$ to 6 th intervals in old specimens and postmedian band usually interrupted on 5th and 7th intervals.

Forehead between eyes nearly as wide as base of rostrum, with dense yellowish grey scalelike setae. Eyes weakly convex. Rostrum as long as pronotum, weakly curved, weakly tapered apically in lateral view; dorsum subconfluently punctate, clothed with yellowish grey setae behind antennae, the setae become thinner anteriorly. Antennae inserted before middle of rostrum; scape almost as long as length of funicle; funicle with 1st segment twice as long as broad, 2nd $3 / 5$ times as long as 1 st, 3 rd to 7 th gradually getting longer apically, 3 rd about half as long as $2 \mathrm{nd}$, 7 th subequal to $2 \mathrm{nd}$; club almost as long as basal four segments of funicle combined.

Prothorax 1.4 times as wide as long, subparallel-sided from base to middle, thence rounded and narrowing to weak subapical constriction, weakly emarginate at apex. Scutellum densely clothed with yellowish grey setae. Elytra oblong-ovate, 1.4 times as long as wide. Legs with fore tibiae weakly sinuate internally.

Metasternum and venter with basal two ventrites weakly depressed in middle.

Aedeagus with median lobe weakly acuminate at apex.

Female. Resembles male, except 2.3-2.5 mm in length; rostrum slender, slightly shorter than head and pronotum combined; antennae inserted in middle of rostrum; legs with fore 
tibiae not roundly dilated internally at apex, and venter with basal two ventrites flattened in middle. Spermatheca J-shaped, gland close to duct.

Specimens examined. Japan: Honshu. Arimoto, Wakayama City, 50 exs., 3. x. 2001, I. Matoba. Tahara, Koza-machi, Wakayama Pref., 30 exs., 5. x. 2002, I, Matoba. Japan: Shikoku. Tarumi, Matsuyama, 3 exs., ix. 1976, Y. Notsu. Japan: Kyushu. Mt. Atago, Fukuoka City, 1 ex, 26. vi. 1959, Y. Miyakate. Hara, Fukuoka City, 6 exs., 11. viii. 1977, S. Miyamoto; 3 exs., 8. viii. 1977, S. Miyamoto. Ainoshima I., Fukuoka, 18 exs., 25. viii. 1981, K. Kido. Nata, Fukuoka City, 3 exs., 5. v. 1997, K. Morimoto; 31 exs., 18. v. 1997, K. Morimoto; 18 exs., 13. vi. 1998, K. Morimoto. Hakozaki, Fukuoka City, 45 exs., 8. vi. 1998, H. Kojima; 41 exs., 10. vi. 1998, H. Kojima. Tatsudayama, Kumamoto, 1 ex., 30. iii. 1960, Y. Miyatake; 2 exs., 22. v. 1974, K. Morimoto; 1 ex., 23. vi. 1974, N. Yoshida; 1 ex., 29. iv. 1977, K. Morimoto. Korea. Ora-dong, Cheju I., 13 exs., 27. iv. 1990, K. Morimoto; 2 exs., 23. vii. 1990, K. Morimoto; 26 exs., 28. vii. 1990, K. Morimoto.

Distribution. Japan (Honshu, Shikoku, Kyushu), Korea (Cheju I.).

Biological note. Overwintering adults emerge from the end of April to the beginning of May, and they are attracted to the flowers of Melia azedarach (Sendan in Japanese). Eggs are laid in the stamen of flower and the larvae consume the style and ovary inside. Mature larvae exit the host and pupation takes place in the ground. New adults emerge from June, feed on young leaves and often found in the leaf roll gall induced by Metaphylla uei Y. Miyatake of Psyllidae.

Orsophagus subfasciatus sp. nov.

(Figs. 61-62, 77-78, 89-91, 106-107)

Description. Male. Length: 1.6-1.7 mm. Integument black, apical half of rostrum often paler, antennae and legs yellowish brown; clothed with recumbent grey to yellowish grey scale-like setae with silken shine, pronotum and elytra mixed with brown scale-like setae foming maculation as follows: pronotum often fainly with two pairs of brownish pacthes on each side around middle, elytra with brownish subbasal pacthes on 3rd and 5th intervals, and postmedian and subapical brownish bands, of which the former is interrupted on 1st and 5th intervals and the latter is on 1st and 7th intervals, often also on 2nd interval.

Forehead between eyes nearly as wide as base of rostrum, with greyish setae. Eyes faintly convex. Rostrum longer than pronotum (6:5), evenly curved, faintly tapered apically in lateral view; dorsum subconfluently punctate, with greyish setae behind antennae, the setae become thinner anteriorly. Antennae inserted slightly before middle of rostrum; scape slightly longer than length of funicle; funicle with 1st segment about twice as long as broad, 2nd 3/5 times as long as 1 st, 3rd to 7 th gradually getting longer apically, 3rd about half as long as $2 \mathrm{nd}$, 7 th as long as 2 nd; club as long as basal five segments of funicle combined. 
Prothorax 1.5 times as wide as long, truncate on anterior margin, subparallel-sided on basal half, thence weakly curved and narrowing to weak subapical constriction. Scutellum subtriangular, longer than broad, densely clothed with greyish setae. Elytra ovate, 1.2 times as long as wide, weakly rounded laterally, widest slightly before middle.

Venter with basal two ventrites flattened in middle.

Aedeagus with median lobe subtruncate at apex.

Female. Resembles male except 1.6-1.8 $\mathrm{mm}$ in length; rostrum slender, slightly shorter than or nearly as long as head and pronotum combined; antennae inserted behind middle of rostrum, and venter with basal two ventrites slightly inflated in middle. Spermatheca commashaped, with gland not so close to duct.

Holotype, male (Type No. 3202, ELKU), Japan: Ryukyus. Ushiku-mori, Iriomote I., 11. iii. 1964, K. Morimoto.

Paratypes. Japan: Ryukyus. [Okinawa-hontô I.] Shuri, 1 male, 8. viii. 1969, H. Makihara. [Ishigaki-jima I.] Mt. Omoto, 4 males and 2 females, 14. x. 1963, Y. Hirashima; 1 male, 14. x. 1963, S. Miyamoto; 3 males and 3 females, 7. iv. 1990, H. Kojima; 7 males and 3 females, 7. iv. 1990, T. Hanatani; 3 females, 8. iii. 1990, Y. Okushima; 1 female, 10-18. iv. 1990, T. Hanatani; 1 male, 19. vi. 1977, H. Irie; 1 male, 30-31. iii. 1994, N. Takahashi. Yoshihara, 1 female, 15. x. 1963, K. Morimoto. Mt. Kaara, 1 male, 28. x. 1963, Y. Hirashima. Nagura, 1 male and 1 female, 21. x. 1962, M. Chujo. Mt. Banna, 3 females, 7-9. ix. 1969, H. Makihara; 1 female, 23-26. v. 1990, K. Morimoto; 1 male and 2 females, 21. iii. 1990, H. Kojima. [Iriomote-jima I.] Same locality as holotype, 1 male, 11. iii. 1964, Y. Miyatake. Mt. Ushiku, 1 male and 1 female, 7-10. xi. 1963, G. A. Samuelson. Shirahama, 12 males and 6 females, 23. viii. 1962, M. Chujo. Hoshidate, 1 female, 8.viii.1962, M. Sato \& Y. Arita; 4 males and 7 females, 31. viii-5. ix. 1969, H. Makihara. Utara Bridge, nr. Urauchi River, 1 male and 1 female, 8. ix. 1963, G. A. Samuelson. Nakamagawa-rindô, 11 males and 8 females, 20. iii. 1990, H. Kojima. Ôtomi, 1 male, 21. iv. 1993, H. Kojima. Ôhara-Mihara, 6 males and 3 females, 19. iv. 1993, H. Kojima. Taiwan. Yangmingshan, Taipei Hs., 3 males and 1 female, 28. iii. 1965, Y. Hirashima; 1 male, 24. viii. 1966, H. Sasaji; 1 male, 14. iv. 1967, T. Shirozu; 1 male and 1 female, 25. v. 1965, Y. Miyatake. Thailand. Fang, 1 female, 13. vi. 1965, K. Morimoto.

Distribution. Japan (Ryukyus: Okinawa-hontô, Ishigaki-jima \& Iriomote-jima Is.), Taiwan, Thailand.

Biological note. Weevils are attracted to the several flowering trees including Melia azedarach in the Ryukyus.

Comments. This species is similar to O. trifasciatus, but is easily separable from it by the smaller body and the different proportions of pronotum and elytra. They occur allopatrically. 

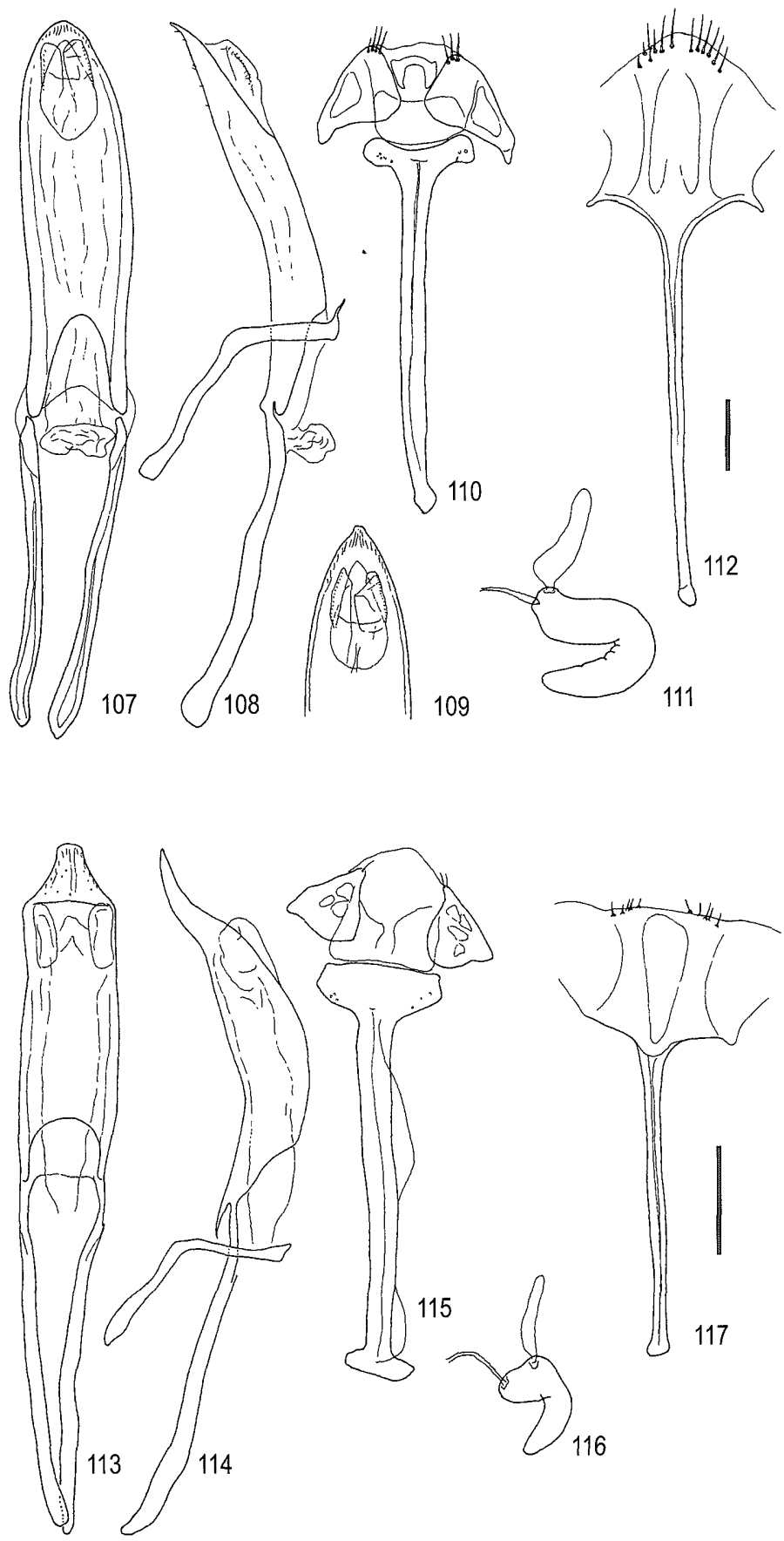

Figs. 107-117. Male and female genitalia of Orsophagus spp.: 107-112. O. trifasciatus; 113-117. O. subfasciatus; 107, 113. aedeagus, dorsal; 108, 114. ditto, lateral; 109. apex of aedeagus; 110,115 . sternite 8 and spiculum gastrale; 111,116 . spermatheca; 112, 117. sternite 8 , female. Scale $=0.1 \mathrm{~mm}$. 


\section{Genus Parimera Faust}

Parimera Faust, 1896: 146 (type species: Parimera signata Faust, herein designated; Anthonominorum). -Heller, 1915: 226 (key). -Schenkling \& Marshall, 1934: 69 (Anthonominae). -Alonso-Zarazaga \& Lyal, 1999: 73 (Curculioninae: Acalyptini).

Integument often with maculation in color. Antennae with funicle 7-segmented. Rostrum not carinate dorsally; antennal scrobe with dorsal carina not rigidly defined, running lower half or toward beneath base of eye. Tergite 7 broadly exposed, tapered caudally, subtriangular, often nearly perpendicular to axis of body in male or obliquely exposed in female; tergite 8 (male) longer than broad. Femora dentate at least on hind femora, often denticle obsolete. Claws widely diverged, toothed indefinitely at base. Procoxae narrowly distant. Ventrites arcuately convex ventrally, 5th ventrite generally longer than (male) or nearly as long as (female) 3rd and 4th ventrites combined. Aedeagus narrow, acuminate and provided with long hairs on each side at apex, with V-shaped orificial sclerite; inner sac with spiculate sclerites.

Comments. After examination of the type species described by Faust, Heller and Voss, this genus appeared to have been confused with Tithene Pascoe. Both genera are, however, separable as noted in our key. And the following species described in Parimera must be transferred to Tithene.

Tithene obscura (Faust), comb. n.

Parimera obscura Faust, 1896: 148. Distribution. Philippines.

Tithene uniformis (Faust), comb. $\mathbf{m}$.

Parimera uniformis Faust, 1896: 148. Distribution. Tanimbar I.

Tithene vitticollis (Heller), comb. $\mathbf{n}$.

Parimera vitticollis Heller, 1900: 37. Distribution. Sulawesi

Tithene trivittata (Heller), comb. $\mathbf{n}$.

Parimera trivittata Heller, 1915: 225, 227. Distribution. Philippines (Luzon).

Tithene negrito (Heller), comb. $\mathbf{n}$.

Parimera negrito Heller, 1915: 225. Distribution. Philippines (Luzon).

Tithene subarmata (Heller), comb. $\mathbf{n}$.

Parimera subarmata Heller, 1925: 226. Distribution. Sumatra.

P. fusca Voss (1961) from Java is unknown to us, but it may belong to the genus Tithene judging from the original description.

Parimera (?) dimidiata Voss (1937) from Java is concluded to be a synonym of Telphasia diluta Pascoe (Fig. 16) from Sumatra after the examination of a cotype at SMTD. Though Telphasia Pascoe is now classified in Anthonomini (Alonso-Zarazaga \& Lyal, 1999), it is incorrect and the position within Curculioninae is uncertain (Kojima \& Idris, 2004). 
Telphasia diluta Pascoe, 1885: 236.

= Parimera dimidiata Voss, 1937: 150. syn. $\mathbf{n}$.

As a result, only the following three species are classified in Parimera.

\section{Parimera signata Faust}

Faust, 1896: 147. Distribution. Philippines (Luzon I.).

2. Parimera vittata Faust

Faust, 1896: 148. Distribution. Java.

3. Parimera palmara Voss

Voss, 1940: 68 (Parimera palmarum Voss). Distribution. Sumatra.

Two new species are herein described from Japan and Taiwan.

\section{Parimera flava sp. nov.}

(Figs. 8, 21, 63-64, 71, 92-93, 98-100, 108-109)

Description. Male. Length: 2.0-2.2 mm. Integument yellowish brown, scutellum often darker; clothed with silken shine recumbent setae.

Forehead between eyes nearly as wide as base of rostrum, with silky shine setae. Eyes faintly convex. Rostrum shorter than pronotum (4:5), weakly curved and tapered apically in lateral view; dorsum subconfluently punctate, with silky shine setae behind antennae, the setae become thinner and inconspicuous apically. Antennae inserted at apical 1/3 of rostrum; scape longer than length of funicle; funicle with 1st segment twice as long as broad, 2nd half as long as 1 st, 3rd to 7 th subequal in length, a little shorter than 2nd; club nearly as long as basal four segments of funicle combined.

Prothorax 1.35 times as wide as long, subparallel-sided on basal half, thence curved and narrowing to weak subapical constriction. Scutellum triangular. Elytra 1.25 times as long as wide, weakly rounded laterally, widest at basal $1 / 3$. Legs with femora edentate except hind femora toothed indefinitely. Tarsal claws toothed at base minutely.

Venter with basal two ventrites flattened in middle; 1st ventrite with a pair of small hairy tufts in middle of posterior part.

Aedeagus with median lobe tapered apically and curved in lateral view.

Female. Resembles male, except 2.2-2.4 mm in length; meso- and metathoraces often darker; rostrum a little shorter than pronotum; antennae inserted slightly before middle of rostrum; prothorax 1.40 times as wide as long; venter with basal two ventrites inflated in middle and 1 st ventrite absents a pair of small hairy tufts. Spermatheca C-shaped, with gland close to duct. 
Holotype, male (Type No. 3203, ELKU), Japan: Ryukyus. Koshiyama, Okinoerabu I., 31. vii-2. viii. 1968, H. Makihara. Paratypes. Japan: Ryukyus. [Okinoebaru-jima I.] 2 males and 5 females, same data as holotype. China, 1 male, 3. iv. 1973, S. Kimoto; 1 male and 1 female, 4. iv. 1973, S. Kimoto. [Okinawa-hontô I.] Chinen-son, 1 male and 3 females, 24. ix. 1962, M. Kina. Tamagusuku-son, 1 female, 26. ix. 1962, M. Kina. Izumi, 1 female, 21. x. 1963, S. Miyamoto. Yona, 1 male, 25-28. iv. 1965, Y. Hirashima.

Distribution. Japan (Ryukyus: Okinoebaru-jima \& Okinawa-hontô Is.).

Comments. This species is easily separable from congeners in having the smaller body of concolorous yellowish brown, the edentate fore and middle femora and the obsoletely toothed hind femora.

\section{Parimera subflava sp. nov.}

(Figs. 94-95, 101-103, 110-111)

Description. Male and female. Very similar to P. flava sp. nov. from Japan, but differs from it by the smaller body, length: 1.8-1.9 mm (male), 2.0-2.1 mm (female); integument yellowish brown except rostrum, often head darker in female; rostrum nearly as long as pronotum and antennae inserted in middle of rostrum in female; prothorax 1.25-1.30 times as wide as long, and aedeagus with median lobe more tapered apically in dorsal view and more curved in lateral view than that of $P$. flava.

Holotype, male (Type No. 3204, ELKU), Taiwan. Shi Nan Shan, near Liu Lui, 15. vii. 1986, K. Baba.

Paratypes. Taiwan. Kukuan, Taichung Hs., 6 males and 12 females, 11. iv. 1991, H. Kojima. Yu Shih, (Alt. 1900m), Nantou Hsien, 3 males and 3 females, 4. vii. 1986, K. Baba. Sungkang, Nontou Hs., 2 males and 1 female, 7. vii. 1978, T. Mikage; 1 male, 8. vii. 1978, T. Mikage. Hohuanchi-Sungkang, Nantou Hs., 3 females, 24. vi. 1976, H. Makihara. Mt. Shitoushan, Miaoli Hs., 1 male, 3. vi. 1976, H. Makihara. Tsuifeng, 1 male and 1 female, 26. vii. 1971, Y. Miyake. Thu Yun Shan, near Liu Kui, 3 males and 8 females, 20. vi. 1986, K. Baba; 2 males and 7 female, 23. vii. 1986, K. Baba. 5 males and 8 female, same data as holotype; 3 males and 5 females, 22. vi. 1986, K. Baba. Tun Chih, near Liu Kui, 2 males and 6 females, 2. vi. 1986, K. Baba. Shyk Shan, Near Liu Kui, 2 males, 17. vi. 1986, K. Baba; 4 males and 2 females, 28. vi. 1986, K. Baba; 1 female, 9. viii. 1986, K. Baba. Near Fenchifu, Chiai Hs., 1 female, $10-$ 11. iv. 1995, H. Kojima. Sha Ping, Near Liu Kui, 1 male, 19. vi. 1986, K. Baba. MeishanTinchi, (Alt. 800-2300m), Kao Hsiung Hs., 1 female, 29. vi. 1986, K. Baba.

Distribution. Taiwan. 

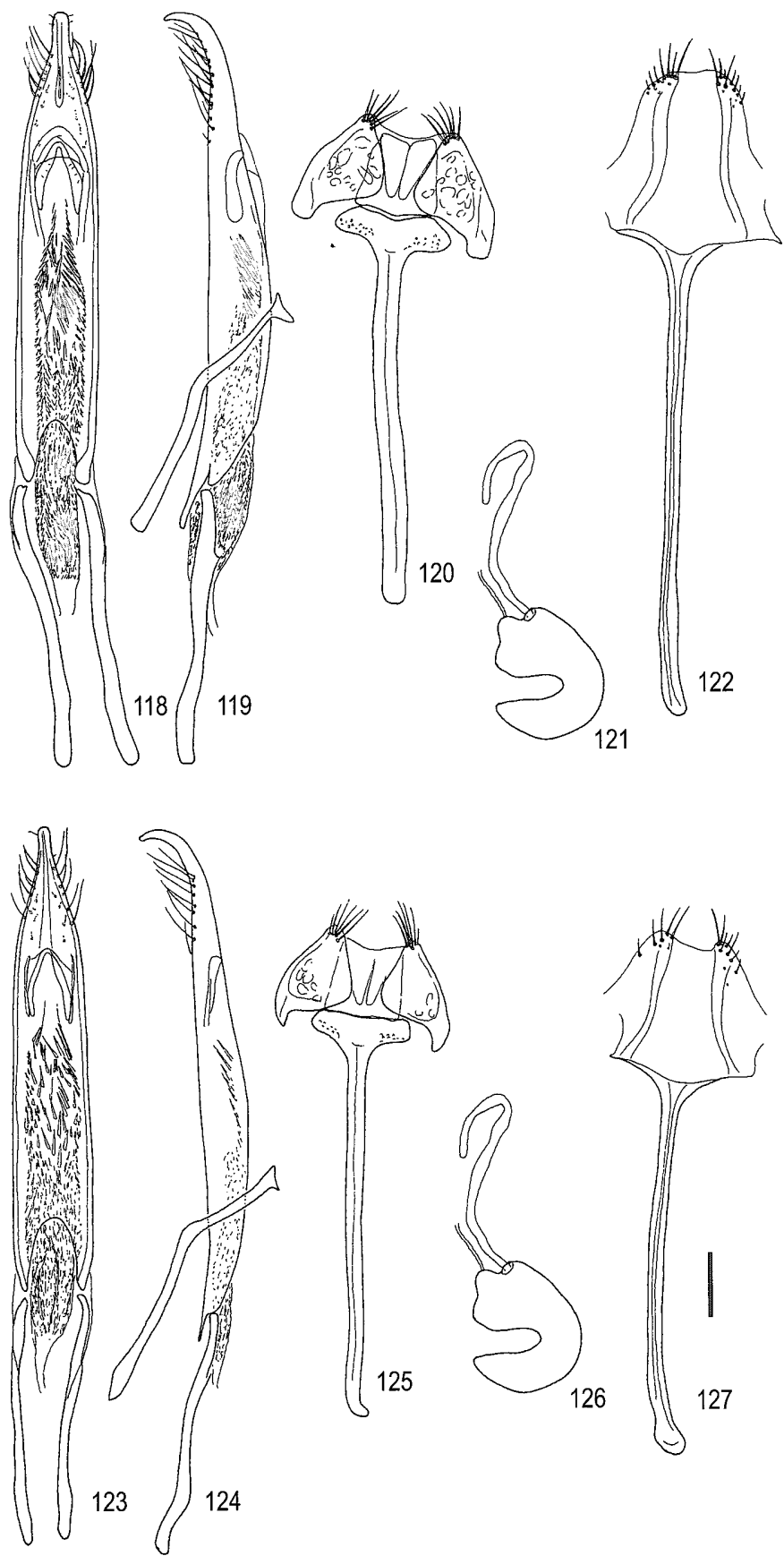

Figs. 118-127. Male and female genitalia of Parimera spp.: 118-122. P. flava; 123-127. P. subflava; 118, 123. aedeagus, dorsal; 119, 124. ditto, lateral; 120, 125. sternite 8 and spiculum gastrale; 121,126 . spermatheca; 122,127 . sternite 8 , female. Scale $=0.1 \mathrm{~mm}$. 


\section{Genus Amorphoidea Motschulsky}

Amorphoidea Motschulsky, 1858: 78 (type species: Amorphoidea arcuata Motschulsky, subsequently designated by Marshall, 1926). -Faust, 1893: 152 (Laemosacciden). -Marshall, 1926: 346 (Anthonominae). -Voss, 1937: 152 (Trypetinae). -Schenkling \& Marshall, 1939: 10 (Erirhininae). -Alonso-Zarazaga \& Lyal, 1999: 73 (Curculioninae: Acalyptini). Ecthetophyga Pierce, 1912: 158 (type species: Ecthetophyga gossyppi Pierce; Menemachina: Menemachini). -Zimmerman, 1994: 662 (=Amorphoidea).

Integument with setae not maculate or fasciate. Antennae with funicle 7-segmented. Rostrum weakly carinate dorsally in male. Antennal scrobe with dorsal carina sharply defined, running to upper half of eye. Femora dentate, teeth of hind pair greater than those of fore and middle pairs or as large as fore pair. Tarsal claws widely separated, usually toothed at base. Procoxae narrowly distant. Tergite 7 broadly and obliquely exposed; tergite 8 (male) transverse. Venter weakly convex ventrally, 5th ventrite shorter than 3 rd and 4th ventrites combined. Aedeagus produced in middle and provided with long hairs on each side at apex, with a pair of orificial sclerites; inner sac densely spiculate.

Amorphoidea is associated with the inflorescence of Malvaceae.

Comments. Motschulsky (1858) described Amorphoidea in 'Erirhinides' with 13 species. Later, nine species were described in Amorphoidea by Motschulsky (1866), Faust (1895, 1898, 1899), Hustache (1929), Voss (1937), Marshall (1937), Subramanian et al. (1975) and Rheinheimer (1991).

Marshall (1926) placed Amorphoidea in Anthonominae, designated A. arcuata as the type species, redefined and transferred two species, A. rufescens Motschulsky and A. angusticollis Motschulsky, to Imerodes in Tychiinae.

The senior author was able to examine holotype and cotype specimens described by Motschulsky and Faust at SMTD, and recently Kojima \& Matoba (2002) transferred A. nigra Motschulsky and A. pilosa Faust to Morimotozo. And, following species are concluded to be not congeneric with Amorphoidea, but belong to Ochyromerini in their ventral features thought the positions within the tribe are uncertain: A. flavipennis Motschulsky and A. flavipes Motschulsky.

Marshall (1937) synonymized Imera Pascoe (type species: I. pedestris Pascoe) with Amorphoidea, but Imera is resurrected here, and the two species, A. basalis Motschulsky from Ind. or. and $A$. dorsalis Faust from the Philippines are assigned to it.

Imera basalis (Motschulsky), comb. n.

Amorphoidea basalis Motschulsky, 1858: 79.

Imera dorsalis (Faust), comb. n.

Amorphoidea dorsalis Faust, 1895: 12. 
Amorphoidea coimbatorensis described by Subramanian et al. (1975) from south India, which infests coconut inflorescences, is unknown to us, but it may not be congeneric.

Rheinheimer (1991) described a new species, A. linospadicis from Australia. According to the description, the rostrum is slender and the fore femora and its teeth are slightly greater than those of middle and hind pairs. These features indicate the affinity with Tithene and the position should be reinvestigated.

Zimmerman (1994) synonymized Ectetophyga Pierce with Amorphoidea and the type species, E. gossypi Pierce, was transferred to Amorphoidea. However, it is a synonym of A. lata Motschulsky (new synonym). He also classified a species, Eudela castanea Lea from Australia in Amorphoidea, but it is not a member of Amorphoidea as mentioned above.

Ramamurthy \& Ghai (1989) described a species collected on the flowers of cotton as the second species of Derelomorphus from India and Sri Lanka, but it is a member of Amorphoidea and similar to A. arcuata Motschulsky.

Fourteen species are now assigned to Amorphoidea, of which two are incertae sedis and nine (indicated by asterisk) were not examined.

\section{Amorphoidea arcuata Motschulsky}

Motschulsky, 1858: 78. Distribution. Ind. or.

2. Amorphoidea fuscirostris Motschulsky*

Motschulsky, 1858: 80. Distribution. Ind. or.

3. Amorphoidea lata Motschulsky

Motschulsky, 1858: 79. Distribution. Ind. or.

= Ecthetophyga gossypi Pierce, 1912: 158., syn. n.

4. Amorphoidea rufipes Motschulsky*

Motschulsky, 1858: 81. Distribution. Ind. or.

5. Amorphoidea rugosa Motschulsky*

Motschulsky, 1858: 81. Distribution. Ind. or.

6. Amorphoidea seriata Motschulsky*

Motschulsky, 1858: 80. Distribution. Ind. or.

7. Amorphoidea testacea Motschulsky*

Motschulsky, 1858: 81. Distribution. Ind. or.

8. Amorphoidea rufotestacea Motschulsky*

Motschulsky, 1866: 433. Distribution. Sri Lanka

9. Amorphoidea rufa Hustache*

Hustache, 1929: 52. Distribution. Indo-China.

10. Amorphoidea pectoralis Marshall

Marshall, 1937: 473. Distribution. Java. 
11. Amorphoidea semirubra Voss

Voss, 1937: 153. Distribution. Java.

12. Amorphoidea subfluva (Ramamurthy \& Ghai), comb. m.

Ramamurthy \& Ghai, 1989: 145. Distribution. Sri Lanka, India.

= Derelomorphus subfluvus Ramamurthy \& Ghai

Incertae sedis

13. Amorphoidea coimbatorensis Subramanian*

Subramanian, 1975: 826. Distribution. India.

14. Amorphoidea linospadicis Rheinheimer*

Rheinheimer, 1991: 189. Distribution. Australia.

Amorphoidea is very similar to Eudelodes Zimmerman which was established for Amorphoidea bicolor Faust from New Guinea and Australia, and only differs by the dentate fore femora.

\section{Amorphoidea lata Motschulsky}

(Figs. 29-34, 36, 41, 42, 52, 89, 90, 96, 102-106)

Amorphoidea lata Motschulsky, 1858: 79. -Woodworth, 1922: 75-81 (biology). -Otanes \& Butac, 1935: 149 (biology, control). -Miwa \& Inamura, 1938: 2. -Schenkling \& Marshall, 1939: 10. -Kalshoven, 1981: 521. -Miyano, 1994: 208 (record from N.

Mariana). -Morimoto \& Kojima, 2003: 55, figs. 4, 5 (record from Japan: Ryukyus).

Amorphoidea lata (?): Voss, 1937: 152.

Ecthetophyga gossyppi Pierce, 1912: 158. sym. nov.

Amorphoidea gossyppi: Zimmerman, 1994: 662.

Redescription. Male. Length: 3.2-4.3 mm. Integument with variation in color. Pale brown to dark brown, antennae and legs paler; clothed with fine recumbent brownish setae.

Forehead between eyes slightly narrower than base of rostrum. Eyes convex. Rostrum shorter than pronotum (4:5), nearly straight, with faint curvature above point of antennal insertion, weakly tapered apically in lateral view; dorsum flattened, with faint five rows of carinae behind antennal insertion. Antennae inserted before middle of rostrum; scape barely reaching anterior margin of eye, as long as funicle; funicle with 1st segment 2.0-3.0 times as long as broad, 2nd 3/5 times as long as 1 st, 3rd to 7 th very faintly become longer apically, 7 th transverse, $2 / 3$ times as long as 2 nd; club nearly as long as basal two segments of funicle combined.

Prothorax 1.35-1.45 times as wide as long, widest at basal 1/3, slightly narrower than width of elytra at this point in large specimen, weakly curved to middle, thence roundly narrowing 
to subapical constriction. Scutellum triangular. Elytra slightly longer than wide, very weakly rounded laterally, widest at middle. Fore femora each with a tooth, which is nearly as great as that of hind pair and curved at apex. Fore tibiae sinuate internally at basal $1 / 3$ and narrowed to base, about half as broad as apex.

Venter with basal two ventrites depressed in middle.

Female. Resembles male, except 3.0-3.9 mm in length; body thinner; rostrum nearly as long as pronotum, weakly curved in lateral view, dorsum without carinae; antennae inserted in middle or slightly behind middle of rostrum; prothorax widest near base, narrower than width of elytra and venter with basal two ventrites flattened in middle.

Specimens examined. Japan: Ryukyus. Hoshidate, Iriomote I., 85 exs., 31. iii. 1990, H. Kojima leg. Yoshihara, Ishigaki I., 1 ex., 5. vii. 1993, K. Morimoto leg. Yonehara, Ishigaki I., 5 exs., 6. vii. 1993, H. Kojima leg. Philippines. Alabel, S. Cotabato, 32 exs., 4. x. 1989. Snfabian, Pang., 40 exs., 24. x. 1989. Sn. Juan, I. Sur., 22 exs., 30. i. 1990. Batak, Ilocos Norte, 71 exs., 10. iii. 1990. Piat, Cagayan, 16 exs., 20. ii. 1990 (all specimens were collected by R. G. David on cotton). Borneo. Nord-Borneo, 2 females, ex. coll. Fruhstorfer (DEI). Marianas: Guam I. GUAM I., Marianas, 1 mi.SE of Asan, 4 exs., 4. Nov. 1947, H. S. Dybas leg. (on Hibiscus tiliaceus); 1 ex., 31. Oct. 1947, alt. 600-800 ft., H. S. Dybas leg.; 1 ex., 5. Nov. 1947, alt. 600-800 ft., H. S. Dybas leg. Com Mar Hill, Guam, 7 exs., I-30-48, K L Maehler. Guam; Yigo, Mariana Is., 1 ex., Aug. 1952, N. L. H. Krauss. Talofufo to Umatic, GUAM, 1 ex., I-25-49, R. W. L. Potts. Guam: Talofofo, 1 ex., August, 1952, N. L. H. Krauss. Guam Is., 3 exs., XII-13-47, K. L. Maehler (on Thespesia populnea).

Distribution. Japan (Ryukyus: Ishigaki-jima \& Iriomote-jima Is.), Philippines, Marianas (Anatahan, Guam-new record), Malaysia (Borneo), Indonesia (Java).

Biological note. Amorphoidea lata is well-known as one of the most important pests of cotton in the Philippines. The life history was studied by Woodworth (1922) and Otanes and Butac (1935) including its control measures. The eggs are laid in the tissue of opened flowers, the sheath of the ovary or the staminal column. The larvae consume the whole contents and cause the flowers to fall down onto the ground without producing mature seeds or fiber. The mature larvae exit the host and pupate in the soil. According to Woodworth (1922), $A$. lata also breeds in the flower of Thespesia lampas, and the adults feed on the flowers of other Malvaceae. Many adults were captured on flowers of Hibiscus tiliaceus in Japan and Guam, and also from Thespesia populnea in Guam.

Comments. Amorphoidea rufa described by Hustache (1929) from Cochin-China is similar to pale brown form of $A$. lata or possibly conspecific with this. Amorphoidea lata is also similar to A. arcuata Motschulsky and A. semiruber Voss, but differs from them by the larger and more ovate body and the concolorous coloration, respectively. 


\section{Genus Imera Pascoe, stat. rev.}

Imera Pascoe, 1885: 236 (type species: Imera pedestris Pascoe, by monotypy; Anthonominae). -Marshall, 1926: 347 (=Amorphoidea).

Similar to Amorphoidea, but differs in the following characters: Integument with bicolorous scale-like setae forming maculation, at least setae of scutellum different in color. Rostrum carinate dorsally at least in male; antennal scrobe with dorsal carina conspicuous, running to lower half of eye and concealing antennal socket beneath it. Tarsal claws moderately diverged. Venter with 5 th ventrite nearly as long as $3 \mathrm{rd}$ and 4 th ventrites combined at least in male. Aedeagus with V-shaped sclerite at orifice.

\section{Imera formosana sp. nov.}

(Figs. 27, 28, 45, 75-79, 91, 92)

Description. Male. Length: 2.4-2.8 mm. Dark reddish brown, head and rostrum black, lateral sides of prothrax, legs and underside yellowish brown except dark meso- and metathoraces; clothed with recumbent yellowish grey with silky shine and fuscous scale-like setae, which are arranged on pronotum, scutellum, elytra and tergite 7 as follows: pronotum with fuscous setae on median dark area and yellowish grey setae on lateral sides, elytra with yellowish grey setae along basal margin and on 1st interval including scutellum, remaining area mainly with fuscous setae, irregularly and sparsely mixed with yellowish grey setae, tergite 7 with fuscous setae except lateral sides with yellowish grey setae.

Forehead between eyes $3 / 5$ times as wide as base of rostrum. Eyes weakly convex. Rostrum shorter than pronotum (4:5), weakly curved and tapered apically in lateral view; dorsum weakly carinate on basal $2 / 3$ and slightly narrowed before antennal insertion in dorsal view. Antennae inserted in middle of rostrum; scape exceeding anterior margin of eye when retracted, as long as funicle; funicle with 1st segment 1.5 times as long as broad; 2 nd 3/5 times as long as 1st, 7th transverse, twice as broad as long.

Prothorax 1.3 times as wide as long, subparallel-sided on basal $1 / 3$, thence curved and narrowing to weak subapical constriction. Elytra slightly longer than broad, widest at basal 1/3. Fore femora each with a small triangular tooth, which is less than $1 / 4$ times as breadth as femora and nearly as great as those of middle pair.

Venter with basal two ventrites flattened in middle.

Female. Resembles male, except $2.6-3.0 \mathrm{~mm}$ in length; rostrum slightly shorter than prothorax and antennae inserted just a little behind middle of rostrum.

Holotype male (Type No. 3205, ELKU), Taiwan. Kenting, Ping Tung Hsien, 2. iv. 1965, S. Hirashima. Paratypes. Taiwan. 1 male, same data as holotype (ELKU). Same locality as holotype, 2 males and 1 female, 24-26. v. 1975, S. Imasaka (ELKU); 2 males and 1 female, 
3. v. 1971, K. Sakai (DEI) ; 1 female, 28. iii. 1972, K. Masumoto (DEI). Thu Yun Shan, near Liu Kui, 1 female, 20. vi. 1986, K. Baba (ELKU).

Distribution. Taiwan (southern part).

Comments. Imera formosana is similar to $I$. dorsalis (Faust) from N. Luzon, the Philippines, but the body is smaller, the integument is darker and the fore femoral tooth is smaller than those of $I$. dorsalis. I. formosana is also similar to I. basalis (Motschulsky) from Ind. or., but $I$. basalis bears the rostrum longer and the hind femora with long hairs along the caudal margin between the base and the tooth.

\section{Taxonomic summary}

Tribe Acalyptini Thomson, 1859

Genus Acalyptus Schoenherr, 1836

A. carpini (Fabricius, 1792) [Palearctic; introduced into North America]

A. sericeus Gyllenhal, 1836 [Palearctic]

Incertae sedis

Acalyptus sabulicolor Motschulsky, 1866 [Sri Lanka]

Acalyptus fasciatus Voss, 1968 [Tonkin]

Genus Orsophagus Roelofs, 1874 stat. rev.

O. trifasciatus Roelofs, 1874 [Japan, Korea]

O. subfasciatus sp. nov. [Japan, Taiwan, Thailand]

Genus Amorphoidea Motschulsky, 1858

= Ecthetophyga Pierce, 1912

A. arcuata Motschulsky, 1858 [Ind. or.]

A. fuscirostris Motschulsky, 1858 [Ind. or.]

A. lata Motschulsky, 1858 [Japan, Philippines, Borneo, Java, Marianas, Ind. or.]

= Ecthetophyga gossypi Pierce, 1912, sym. nov.

A. rufipes Motschulsky, 1858 [Ind. or.]

A. rugosa Motschulsky, 1858 [Ind. or.]

A. seriata Motschulsky, 1858 [Ind. or.]

A. testacea Motschulsky, 1858 [Ind. or.]

A. rufotestacea Motschulsky, 1866 [Sri Lanka]

A. rufa Hustache, 1929 [Indo-China]

A. semirubra Voss, 1937 [Java]

A. pectoralis Marshall, 1937 [Java]

A. subfluva (Ramamurthy \& Ghai, 1989), comb. nov. [Sri Lanka, India] 
= Derelomorphus subfluvus Ramamurthy \& Ghai, 1989

Incertae sedis

Amorphoidea coimbatorensis Subramanian, 1975 [India]

Amorphoidea linospadicis Rheinheimer, 1991 [Australia]

Genus Eudelodes Zimmerman, 1994

Eudelodes bicolor (Faust, 1899) [New Guinea, Australia]

E. atra (Lea, 1915), comb. nov. [Australia]

Genus Imera Pascoe, 1885, stat. rev.

Imera pedestris Pascoe, 1885 [Sulawesi]

I. basalis (Motschulsky, 1858), comb. nov. [Ind. or.]

= Amorphoidea basalis Motschulsky, 1885

I. dorsalis (Faust, 1895), comb. nov. [Philippines: Luzon, Java]

= Amorphoidea dorsalis Faust, 1895

I. formosana sp. nov. [Taiwan]

Genus Parimera Faust, 1896

P. signata Faust, 1896 [Philippines: Luzon]

P. vittata Faust, 1896 [Java]

P. palmara Voss, 1940 [Sumatra]

$P$. flava sp. nov. [Japan]

P. subflava sp. nov. [Taiwan]

Incertae sedis

Parimera fusca Voss, 1961 [Java]

Genus Tithene Pascoe, 1874

T. (Tithene) microcephala Pascoe, 1874 [Malaysia: Sarawak]

T. (T.) vittata Voss, 1937 [Java]

T. (T.) quadrimaculata Voss, 1937 [Java]

T. (T.) proxima Voss, 1937 [Java]

T. (T.) negrito (Heller, 1915) [Philippines: Luzon]

T. (T.) obscura (Faust, 1896), comb. nov. [Philippines]

= Parimera obscura Faust, 1896

T. (T.) uniformis (Faust, 1896), comb. nov. [Tanimbar I.]

= Parimera uniformis Faust, 1896

T. (T.) vitticollis (Heller, 1900), comb. nov. [Sulawesi]

= Parimera vitticollis Heller, 1900 
T. (T.) trivittata (Heller, 1915), comb. nov. [Philippines: Luzon]

= Parimera trivittata Heller, 1915

T. (T.) subarmata (Heller, 1925), comb. nov. [Sumatra]

= Parimera subarmata Heller, 1925

T. (Hypotithene) barbirostris Voss, 1940 [Sulawesi]

Genus Eudela Pascoe, 1885

Eudela rufescens Pascoe, 1885 [Malaysia: Sarawak]

Genus Niseida Pascoe, 1885

N. virginea Pascoe, 1885 [Aru]

Genus Derelomorphus Marshall, 1928

D. eburneus Marshall, 1934 [Malaysia, Singapore]

Genus Nodocnemus Marshall, 1931

N. subfasciatus Marshall, 1931 [Samoa]

N. uniformis Marshall, 1937 [N. Hebrides]

Genus Meredolus Marshall, 1935

M. cocotis Marshall, 1935 [Solomon Is.]

\section{Ackmowledgments}

Thanks are due to those researchers of the institutions noted in the section of material and method for their loan and/or examination of specimens. We also indebted to Charles W. O'Brien of Florida A\&M University and Nico M. Franz of Cornell University for their reading of the manuscript. The senior author also thanks to Rolf Oberprieler of CSIRO for his kindness invited him to Australia as a postdoctoral fellow funded by the Japanese Society for Promotion of Science (JSPS) and J. Yukawa and O. Tadauchi for their encouragement. This study is supported in part by the JSPS Tropical Bio-Resources Research Fund, a fund from the JSPS for Japanese Junior Scientists and the Ryûichi Matsuda Foundation and KAKENHI (16770067) to Kojima.

\section{References}

Alonso-Zarazaga, M. \& C. H. C. Lyal, 1999. A world catalogue of families and genera of Curculionoidea (Insecta: Coleoptera) (excepting Scolytidae and Platypodidae). 315 
pp., Entomopraxis, Barcelona.

Aurivillius, C., 1920. Snytbaggar. Rhynchophora. Svensk Insektfauna utgiven av Entomologiska Föreningen i Stockholm. Vol. 9. Skalbaggar. Coleoptera. Häft. 1: pp. 1-64. Bedel, L., 1884a. Faune des Coléoptères du Bassin de la Seine. Vol. VI. Rhynchophora. Ann. Soc. ent. Fr., (6) 3, Publication Hors Série: 65-80.

Bedel, L., 1884b. Faune des Coléoptères du Bassin de la Seine. Vol. VI. Rhynchophora. Ann. Soc. ent. Fr., (6) 4, Publication Hors Série: 113-128.

Cawthra, E. M., 1966. A redefinition of the subfamily Eugnominae to include the Meriphinae. Trans. r. Soc. N. Z., Zool., 7 (12): 171-178.

Cock, M. J. W., 1985. Does a weevil pollinate coconut palm ?. Curculio, (18) : 8.

Dieckmann, L., 1988. Beiträge zur Insektenfauna der DDR: Curculionidae (Curculioninae: Ellescini, Acalyptini, Tychiini, Anthonomini, Curculionini). Beitr. Ent., 38: 365-468.

Egorov, A. B., V. V. Zherikhin \& B. A. Korotyaev, 1996. Curculionidae. In Lehr, P. A. (ed.) : Key to the Insects of the Russian Far East. Vol. III. Coleoptera. Pt. 3, pp. 249-311, 431516, Vladivostok: Dal'nauk. (In Russian.)

Fabricius, J. C., 1792. Entomologia systematica emendata et aucta. Secundum classes, ordines, genera, species adjectis synonimis, locis, observationibus, descriptionibus. Vol. $1, \mathrm{xx}+538$ pp. Hafniae.

Faust, J., 1893. Notizen über Rüsselkäfer. Stett. ent. Ztg., 54: 145-152.

Faust, J., 1895. Einige neue Luzon-Curculioniden des Museum Tring. Stett. ent. Ztg., 56: 3-21. Faust, J., 1896. Neue Curculioniden aus Java. Stett. ent. Ztg., 57: 136-164.

Faust, J., 1898. Beschreibung neuer Coleoptera von Vorder- und Hinterindien aus der Sammlung des Hrn. Andrewes in London. Curculionidae. Deut. ent. Zeitschr., 1898: 273333.

Faust, J., 1899. Vaggio di Lamberto Loria nella Papuasia orientale. XXIII. Curculionidae. Ann. Mus. Civ. Stor. Nat. Genova, 40: 1-130.

Heller, K. M., 1900. Neue Käfer von Celebes. IV. Abh. Ber. zool. Mus. Dres., 9: 46 pp., 1 pl.

Heller, K. M., 1913. Neue Käfer von den Philippinen. Philipp. J. Sci., 8, D2: 135-161.

Heller, K. M., 1915. Neue Käfer von den Philippinen: III. Philipp. J. Sci., 10, D4: 219-249, $1 \mathrm{pl}$.

Heller, K. M., 1925. Rüsselkäfer von Sumatra gesammelt von Herrn J. B. Corporaal. Zool. Meded., 8: 220-244.

Henderson, A., 1986. A review of pollination studies in the Palmae. Botanical Review, 52: 221-259.

Hoffmann, A., 1954. Fauna de France, 59, Coléoptères Curculionides (Deuxiéme Partie), 720 pp., Paris.

Hong, K. J., A. B. Egorov \& B. A. Korotyaev, 2000. Illustrated Catalogue of Curculionidae in Korea (Coleoptera). In Park, K. T. (eds.): Insects of Korea, (5), 340 pp. 
Hustache, A., 1929. Un nouvel ennemi du cotonnier (Col. Curculionidae). Bull. Soc. ent. Fr., 1929: 52-53.

Kalshoven, L. G. E., 1981. Pest of crops in Indonesia (Revised and translated by P. A. van Der Laan and G. H. L. Rothschild). 701 pp. P.T. Ichtiar Baru-Van Hoeve, Jakarta.

Kissinger, D. G., 1964. Curculionidae of America north of Mexico. A key to the genera. $\mathrm{v}+143$ pp., S. Lancaster, M.A.

Klima, A., 1934. Coleopterorum Catalogus. Pars 140, Curculionidae: Erirrhininae, pp. 1167. Junk, 's-Gravenhage.

Kôno, H., 1930. Langrüssler aus dem japanischen Reich. Ins. Mats., 4: 145-162.

Kojima, H. \& Idris, A. B., 2004. The Anthonomini from Malaysia, with notes on the Oriental taxa (Coleoptera: Curculionidae). Serangga, 9: 103-129.

Kojima, H. \& I. Matoba, 2002. Taxonomic notes on the genus Morimotozo (Coleoptera, Curculionidae). Elytra, 30: 263-272.

Kojima, H. \& K. Morimoto, 2000. Systematics of the genus Sphinxis Roelofs (Coleoptera: Curculionidae). Ent. Sci., 3: 529-556.

Krivolutskaya, G. O., M. E. Ter-Minassian \& A. B. Egorov, 1978. To the knowledge of the beetle fauna-weevil (Coleoptera, Curculionidae) of southern Kuril Islands and Sakhalin. Trudy Biologo-pochbennogo Instituta, 50 (153): 87-101. (In Russian.)

Kuschel, G. A. K., 1952. Los Curculionidae de la cordillera chileno-argentina (1. ${ }^{a}$ parte). Rev. Chile. Ent., 2: 229-279.

Kuschel, G. A. K., 1964. Insects of Campbell Islands. Coleoptera: Curculionidae of the subantarctic islands of New Zealand. Pac. Ins. Monogr., 7: 416-493.

Kuschel, G., 1987. The subfamily Molytinae (Coleoptera: Curculionidae): General notes and descriptions of new taxa from New Zealand and Chile. N. Z. Ent., 9: 11-29.

Kuschel, G., 1992. Apionidae and Curculionidae (Coleoptera) from the Poor Knights Islands, New Zealand. J. r. Soc. N. Z., 12: 273-282.

Kwon, Y. J. \& S.-M. Lee, 1986. Check list of weevils from Korea (Coleoptera: Curculionoidea). Ins. Korea., (6): 57-89.

Lacordaire, J. T., 1866. Histoire naturelles des insectes. Genera des Coléoptères 7, [iv]+620 pp. Paris: Roret.

Lea, A. M., 1915. Descriptions of new species of Australian Coleoptera. Part X. Proc. Linn. Soc. N. S. Wales, 39 (4) : 650-694, 1 pl.

Lepesme, P., 1947. Les Insectes des Palmiers. 903 pp. Paul Lechevalier, Paris.

Lohse, G. A., 1983. Curculioninae. In Freude, H. et al., Die Käfer Mitteleuropas, 11: 78-110, Krefeld.

Lyal, C. H. C. \& T. King, 1996. Elytro-tergal stridulation in weevils (Insecta: Coleoptera: Curculionoidea). J. nat. Hist., 30: 703-773.

Marshall, G. A. K., 1926. On new species of Curculionidae (Col.) from Java and Sumatra. 
Treubia, 8: 342-351.

Marshall, G. A. K., 1928. New Oriental Curculionidae. Ann. Mag. nat. Hist., (10) 2: 537-557. Marshall, G. A. K., 1931. Curculionidae. Ins. Samoa, 4, fasc. 5: 249-346.

Marshall, G. A. K., 1935. Four new Derelominae (Col. Curc.). Stylops, 4: 137-140.

Marshall, G. A. K., 1937a. On Curculionidae from the New Hebrides. Rev. Fr. Ent., 4: 39-43. Marshall, G. A. K., 1937b. New injurious Curculionidae (Col.). Bull. ent. Res., 28: 467-477. Miwa, Y. and M. Inamura, 1938. Some undiscovered pests from Taiwan observed to preclude introduction. Shokubutsu Kensa Shiryo, Taiwan, 7 (4/5): 2. (In Japanese.)

Miyano, S., 1994. Insects of the northern Mariana Islands, Micronesia, collected during the expedition. Nat. Hist. Res., Special Issue, (1): 199-215.

Morimoto, K., 1962a. Preliminary check list of the families Curculionidae (II) and Rhynchophoridae of Japan. Sci. Bull. Fac. Agr., Kyushu Univ., 19 (3) : 341-368.

Morimoto, K., 1962b. Comparative morphology and phylogeny of the superfamily Curculionoidea of Japan. J. Fac. Agr., Kyushu Univ., 11 (4): 331-373.

Morimoto, K., 1962c. Key to families, subfamilies, tribes and genera of the superfamily Curculionoidea of Japan excluding Scoytidae, Platypodidae and Cossininae. J. Fac. Agr., Kyushu Univ., 12 (1) : 21-66.

Morimoto, K., 1983. Synonymic notes on some Japanese weevils of the families Attelabidae and Curculionidae. Esakia, (20): 54.

Morimoto, K. 1984. Curculionidae. In Hayashi, M., K. Morimoto and S. Kimoto, Coleoptera of Japan in Color. IV. 438 pp., 72 col. pls. Hoikusha, Osaka. (In Japanese.)

Morimoto, K. \& H. Kojima, 2003. Synonymic and faunistic notes on some weevils in Japan (Coleoptera: Curculionoidea). Ent. Rev. Jpn., 58: 53-66.

Motschulsky, V., 1858. Insectes des Indes orientales. Étud. Ent., 7: 20-122.

Motschulsky, V., 1866. Essai d'un Catalogue des Insectes de l'île Ceylon. Bull. Soc. nat. Moscou. Section biologique, 39 (2): 393-446.

Nakane, T., 1963. Curculionidae. In Nakane et al., Iconographia Insectorum Japonicorum Colore Naturali Edita, II, 443 pp., 192 col. pls. Hokuryukan, Tokyo. (In Japanese.)

Nyholm, T., 1952. Zur Kenntnis der Curculionidenfauna Schwedens. 3. Die schwedichen Acalyptus-Arten. Ent. Tidskr., 73: 219-227.

O'Brien, C. W. \& G. J. Wibmer, 1982. Annotated checklist of the weevils (Curculionidae senseu lato) of North America, Central America, and the West Indies (Coleoptera: Curculionidae). Mem. Amer. ent. Inst., (34) : i-ix, 1-382.

Otanes, F. Q. \& F. L. Butac, 1935. A preliminary study of the insect pests of cotton in the Philippines with suggestions for their control. Philipp. J. Agr., 6 (2): 147-174, 10 pls.

Pascoe, F. P., 1874. Contributions towards a knowledge of the Curculionidae. J. Linn. Soc. Zool., 12: 1-99.

Pascoe, F. P., 1885. List of the Curculionidae of the Malay Archipelago collected by Dr. 
Odoardo Baccari, L. M. D'Albertis, and others. Ann. Mus. Civ. Stor. Nat. Genova, 2: 201-331, 3 pls.

Pierce, W. D., 1912. Systematic notes and descriptions of some weevils of economic or biological importance. Proc. U. S. nat. Mus., 42: 155-170.

Ramamurthy, V. V. \& S. Ghai, 1989. Studies on Derelomorphus with description of a new species (Coleoptera: Curculionidae). Oriet. Ins., 23: 143-151.

Reitter, E., 1912. Bestimmungs-Schlüssel der mir bekannten europäischen Gattungen der Curculionidae, mit Einschluss der mir bekannten Gattungen aus dem palaearktischen Gebiet. Verh. naturf. Vereines. Brünn, 51: 1-90.

Rheinheimer, J., 1991. Bemerkungen über die australischen Arten der Gattung Amorphoidea Motschulsky sowie Beschreibung einer neuen Art (Coleoptera: Curculionidae). Koleopt. Rundsch., 61: 189-192.

Roelofs, W., 1874. Curculionides recueillis au Japon par M. G. Lewis. Ann. Soc. ent. Belg., 17: $121-176$.

Schenkling, S. and G. A. K. Marshall, 1934. Coleopterorum Catalogus. Pars 139, Curculionidae: Anthonominae, pp. 3-82. Junk, 's-Gravenhage.

Schenkling, S. and G. A. K. Marshall, 1939. Coleopterorum Catalogus. Pars 168, Curculionidae: Addenda, pp. 1-14. Junk, 's-Gravenhage.

Schoenherr, C. J., 1836. Genera et species curculionidum, ... Vol. 1 (1) : i-xv+1-381. Paris, Roret.

Subramanian, T. R., P. Thangavel \& B. V. David, 1975. A new species of Amorphoidea (Curculionidae: Coleoptera) infesting coconut inflorescence. Current Sci., 44 (22) : 825826.

Thomson, G. C., 1859. Skandinaviens Coleoptera, synoptiskt bearbetade, vol. 1, [iv] +296 pp. Lund.

Thomson, G. C., 1870. Bidrag till Sveriges Insect-Fauna. Opusc. Ent., 3: 322-339.

Thompson, R. T., 1992. Observations on the morphology and classification of weevils (Coleoptera, Curculionidae) with a key to major groups. J. nat. Hist., 26: 835-891.

Voss, E., 1937. Ein weiterer Beitrag zur Kenntnis der Curculioniden Javas. Tijdschr. Ent., 80: 127-166.

Voss, E., 1940. Über Rüsselkäfer der indomalayischen Subregion, vorwiegend von Java (Col., Curc.). Tijdschr. Ent., 83: 17-93.

Voss, E., 1953, Über einige in Fukien (China) gesammelte Rüßler. IV. (Col., Curc.) . Ent. Bl., 49: $42-82$.

Voss, E. 1958, Ein Beitrag zur Kenntnis der Curculioniden im Grenzgebiet der orientalischen zur paläarktischen Region (Col., Curc.). Decheniana-Beihefte, 5: 1-139.

Voss, E., 1961. Über einige weitere Curculioniden aus dem indonesischen Raum (Col., Curc.). Treubia, 25: 241-267. 
Voss, E., 1968. Beschreibung einer äthiopischen und zweier orientalischer Curculioniden (Col., Curc.). Ent. Mitt., Hamb., 3 (60): 25-28.

Wibmer, G. J. \& C. W. O’Brien, 1986. Annotated checklist of the weevils (Curculionidae sensu lato) of South America (Coleoptera: Curculionoidea). Mem. Amer. ent. Inst., (39): i-xvi, 1-563.

Woodworth, H. E., 1922. The Philippines cotton boll weevil. Philipp. Agr., 10 (3): 75-81, 1 pl. Zherikhin, V. V. \& A. B. Egorov, 1990. Weevils (Coleoptera, Curculionidae) of the U.S.S.R. Far East (a review of the subfamilies with descriptions of new taxa) 164 pp. BiologicalPedological Institute, Vladivostok. (In Russian.)

Zherikhin, V. V. \& V. G. Gratshev, 1995. A comparative study of the hind wing venation of the superfamily Curculionoidea, with phylogenetic implications. In Pakaluk, J. \& S. A. Slipinski (eds.). Biology, Phylogeny, and Classification of Coleoptera: Papers Celebrating the 80th Birthday of Roy A. Crowson. pp. 633-777, Muzeum i Instytut Zoologii PAN, Warszawa.

Zimmerman, E. C., 1992. Australian weevils. Volume VI. viii+707 pp., CSIRO, Melbourne. Zimmerman, E. C., 1994. Australian weevils. Volume III. x+854 pp., CSIRO, Melbourne. 
